NBER WORKING PAPER SERIES

\title{
THE OWN AND SOCIAL EFFECTS OF AN UNEXPECTED INCOME SHOCK: EVIDENCE FROM THE DUTCH POSTCODE LOTTERY
}

\author{
Peter J. Kuhn \\ Peter Kooreman \\ Adriaan R. Soetevent \\ Arie Kapteyn \\ Working Paper 14035 \\ http://www.nber.org/papers/w14035 \\ NATIONAL BUREAU OF ECONOMIC RESEARCH \\ 1050 Massachusetts Avenue \\ Cambridge, MA 02138 \\ May 2008
}

Please direct correspondence to Peter Kuhn at pjkuhn@econ.ucsb.edu. We thank Herma van der Vleuten (University of Groningen), Kim Paulussen, Kamieke van de Riet, Peter Willems (GfK Benelux), and Jenny van Laar (Bridgis) for their contributions to the data collection process. The data collection was made possible through a grant from the Netherlands Organization for Scientific Research (NWO). Soetevent's research was supported by a grant from the Program of Fellowships for Junior Scholars of the MacArthur Research Network on Social Interactions and Economic Inequality We thank Tobias Klein, Andrew Oswald, Bruce Sacerdote and Linda Waite for helpful comments, as well as seminar participants at the Université de Paris 1, Université de Lyon 2, University of Zurich, Duke University, UCSB, the University of Siena, New York University, and the All-UC labor economics conference at UC Davis. The views expressed herein are those of the author(s) and do not necessarily reflect the views of the National Bureau of Economic Research.

NBER working papers are circulated for discussion and comment purposes. They have not been peerreviewed or been subject to the review by the NBER Board of Directors that accompanies official NBER publications.

(C) 2008 by Peter J. Kuhn, Peter Kooreman, Adriaan R. Soetevent, and Arie Kapteyn. All rights reserved. Short sections of text, not to exceed two paragraphs, may be quoted without explicit permission provided that full credit, including $(\odot)$ notice, is given to the source. 
The Own and Social Effects of an Unexpected Income Shock: Evidence from the Dutch Postcode Lottery

Peter J. Kuhn, Peter Kooreman, Adriaan R. Soetevent, and Arie Kapteyn

NBER Working Paper No. 14035

May 2008

JEL No. C21,D12

\begin{abstract}
In the Dutch Postcode Lottery a postal code (19 households on average) is randomly selected weekly, and prizes - consisting of cash and a new BMW - are awarded to lottery participants living in that postal code. On average, this generates a temporary, unexpected income shock equal to about eight months of income for about one third of the households in a typical winning code, while leaving the incomes of nonwinning, neighboring households unaffected. We study the responses of consumption and reported happiness of both winners and nonwinners to these shocks. Consistent with simple models of in-kind transfers, the overwhelming majority of households who won a BMW convert it into cash. With the exception of food away from home, the only 'own' effects of cash winnings we detect are on durables expenditures and car consumption; these results support a version of the permanent income hypothesis in which durable spending is used to smooth consumption. We detect social effects of neighbors' winnings on two types of consumption: cars and exterior home renovations. Six months after the fact, winning the lottery does not make households happier, nor do neighbors' winnings reduce happiness.
\end{abstract}

Peter J. Kuhn

Department of Economics

UC, Santa Barbara

2127 North Hall

Santa Barbara, CA 93106

and NBER

pjkuhn@econ.ucsb.edu

Peter Kooreman

Tilburg University

Room K 411

PO Box 90153

5000 LE Tilburg

The Netherlands

p.kooreman@uvt.nl
Adriaan R. Soetevent

Universiteit van Amsterdam

Faculty of Economics and Business

Roetersstraat 11

1018 WB Amsterdam

The Netherlands

a.r.soetevent@uva.nl

Arie Kapteyn

RAND Corporation

1700 Main Street

P.O. Box 2138

Santa Monica, CA 90407-2138

kapteyn@rand.org 


\section{Introduction}

The question of how households change their economic behavior when they receive a temporary income shock is of great importance for macroeconomic and fiscal policy, and for one of the most influential hypotheses in economics -the permanent income hypothesis (PIH). A second influential hypothesis in the discipline has been the notion that households' consumption behavior is directly affected by their neighbors, via competitive or imitative processes; see for example Leibenstein (1950), Pollak (1976), Bagwell and Bernheim (1996), and Becker and Murphy (2001). Finally, a fundamental prediction of consumer theory is the notion that households who receive extramarginal in-kind transfers should, if possible, attempt to undo those transfers by converting them to cash (e.g. Moffitt 1984, 1989).

To date, empirical testing of all the above hypotheses has yielded less-than-definitive results, due in part to the lack of credibly exogenous variation in either a household's own income, or in either the income or consumption of its neighbors. Recently, however, progress on testing the PIH has been made by using the random timing of income tax rebates (Agarwal, Liu and Souleles 2007). Regarding social effects, a number of recent studies have used plausibly exogenous variation to study social and neighborhood effects, such as Sacerdote's (2001) study of (randomly assigned) college room mates, and social experiments such as Moving to Opportunity which randomly assign households to neighborhoods (Katz et al. 2001, Kling et al. 2005, Ludwig et al. 2001). To our knowledge however, none of these newer studies of social effects focus specifically on household consumption. We are aware of no experimental tests of simple models of transfers in kind.

In this paper we contribute to all the above research questions using data from the Dutch Postcode Lottery (PCL). Each week, this lottery allocates a prize to participants in a randomly 
chosen postcode (containing 19 households on average). About one third of the Dutch population participates in the lottery. A participant wins $€ 12,500$ per ticket. In addition, one of the participants wins a BMW. From an experimental design perspective, the lottery provides PCL participants in the winning code with an unexpected temporary income shock equal on average to about eight months of income, while leaving all other households' incomes unchanged. In addition, a randomly chosen subet of those households receive a significant part of their transfer in kind (in the form of a new BMW). Because our data include both winning and nonwinning households, and both winning and nonwinning postcodes, this allows us to estimate not only the effects of unexpected, temporary income shocks (both cash and in kind) on a household's own consumption (and, incidentally, happiness), but their effects on its neighbors' consumption and happiness as well. Our consumption and happiness data is drawn from a survey of households in winning and nearby non-winning postcodes six months after PCL prizes were awarded, between September 2003 and July 2006.

Compared to existing evidence on the own effects of income shocks, our approach has the following advantages. Relative to Agarwal et al (2007), the income shocks we observe are much larger (the tax rebates they consider amount to less than one percent of average annual income); in addition our consumption measures are not restricted to items purchased with a single credit card, we have significant detail about the distribution of expenditures across types of consumption (for example, durables versus nondurables), and we have (self-reported) information on other household income, which allows us to compare the effects of lottery winnings on spending to those of other components of income. Limitations relative to their data are a smaller sample size and less information on the timing of expenditure responses to income shocks. A distinction (relevant to the interpretation of the results) is that the income shocks in 
our experiment were almost surely unexpected by their recipients. Relative to Imbens et al.’s (2001) study of lottery winners, we have a larger sample and more detail on types of consumption expenditures. Our income shocks are for the most part smaller than theirs, and temporary, which leads to different predicted effects. Unlike Imbens et al., we do not have any information about our households later than six months after the lottery win.

The current paper is, to our knowledge, the first random-assignment-based study of social effects in household consumption. Another distinctive feature of our analysis of social effects is its partial-population design, in which a subset of the members of a fixed peer group receives an exogenous shock. ${ }^{1}$ Most quasi-experimental studies of neighborhood effects, like the Moving To Opportunity (MTO) studies (Katz et al. 2001, Kling et al. 2005, Ludwig et al. 2001), use what Moffitt (2001) calls group-changing interventions. In group-changing interventions, a randomly selected number of households is given the opportunity to change peer groups (in our case, this would involve moving to a different neighborhood). Since the disruptive effects of residential mobility may directly impact the outcomes under study, the resulting estimates of social effects could be contaminated.

We identify the own and social effects of income shocks on households in two main ways. The first, and simpler approach compares households in winning versus nonwinning postcodes. Among lottery nonparticipants, this provides a clean test for the presence of social effects: in neither case do nonparticipants receive any lottery winnings themselves, yet the PCL randomly exposes those who live in winning codes to income shocks among their neighbors (on average, the PCL injected a total of $€ 217,980$ into a postcode). As long as a household’s postcode-mates are more likely to belong to its consumption reference group than are residents

\footnotetext{
${ }^{1}$ Partial population experiments have however been used in other contexts, for example to estimate the extent of information dissemination and learning among neighbors and friends (Duflo and Saez 2003, Duflo et al. 2004,
} 
of other postcodes, this allows for a clean test of peer effects in consumption. Among lottery participants, the comparison between winning and nonwinning codes estimates a combination of own and social effects, since PCL ticket owners in winning codes are exposed to both own and neighbors' income shocks. In a regression-based estimation approach, we explore effects of the amounts won (both in the household and in its vicinity) on own consumption, using variation in winnings that is generated only by the random selection of winning postcodes in the PCL. We also explore the sensitivity of our results to a wide range of alternative specifications of a household's reference group.

Consistent with simple theories of in-kind transfers (e.g. Moffitt 1984, 1989), we find that the vast majority of BMW winners trade their BMW for cash, despite significant tax or transactions costs associated with this. Consistent with a simple life-cycle model of consumption, we do not detect any own effect of winning the postcode lottery on most components of households' expenditures, including food at home, transportation, and total monthly outlays. Own effects are, however detected for durables expenditures and car consumption. Both of these effects are consistent with a version of the life-cycle consumption model in which (because credit markets are imperfect) households use durables expenditures to smooth consumption in response to unexpected, temporary income shocks (see for example Browning and Crossley 2004). We also detect an effect of temporary income shocks on food expenditures away from home; while these are small in magnitude they are still too large to reconcile easily with a simple life-cycle model.

Turning to social effects, we detect statistically significant effects of neighbors’ lottery winnings on car consumption and exterior home renovations. For example, PCL nonparticipants who live in winning codes are more likely to acquire a new car in the six months after the lottery

Miguel and Kremer 2004). 
win than nonparticipants living in nonwinning codes. Further, we find that nonwinning households who live next door to PCL winners are significantly more likely to purchase a car in the six months after the lottery than nonwinning households located elsewhere, and that nonwinning households living in postcodes where a large number of households won the PCL are more likely to start a major exterior home renovation in the six months since the lottery than nonwinning households located elsewhere. We discuss a number of possible mechanisms that might account for social effects of this nature.

\section{The Dutch Postcode Lottery and the Street Prize}

The Nationale Postcode Loterij (PCL) is the second largest national lottery in the Netherlands, with a revenue market share of 26.6 percent in $2005 .^{2}$ Contrary to the Staatsloterij (State Lottery), the largest Dutch lottery (market share 42.6 percent in 2005), the PCL is a charity lottery: A condition for its license is that at least 50 percent of revenues must be donated to approved charities. Since its inception in 1990 the PCL has grown steadily. In 2005 about 30 percent of the Dutch population participated in the PCL, with an estimated annual expenditure per participant of $€ 175 .^{3}$

The popularity of the PCL is sometimes attributed to its potential to induce regret among nonparticipants (Zeelenberg and Pieters, 2004). In the PCL the lottery ticket number is the participant's 6-digit postcode. ${ }^{4}$ As a result, conditional on a given postcode being the winning code, a nonparticipant in that code knows that he or she would have won a prize for sure had s/he purchased a ticket. Moreover, the weekly award of prizes is widely publicized in the media,

\footnotetext{
${ }^{2}$ Source: College van toezicht op de kansspelen (Government Agency for Lottery Supervision; www.toezichtkansspelen.nl).

${ }^{3}$ Estimate based on the sample described in Section 3.
} 
including - in most cases - a broadcast on national television around 10 pm on Sunday evenings. This five minute program features happy winners and, occasionally, less happy nonwinners. ${ }^{5}$

During our sample period, participants paid from $€ 6.25$ to $€ 6.75$ per ticket, which is debited monthly from their bank account. ${ }^{6}$ There are no restrictions on the number of lottery tickets that can be purchased per participant. ${ }^{7}$ The PCL awards several prizes, ranging from very large ones (around $€ 10$ million, once or twice a year) to very small ones. ${ }^{8}$ In this paper we focus on one specific prize, the weekly Street Prize. If a postcode is selected as the winning code, a prize of $€ 12,500$ per lottery ticket is awarded to participants living in that postcode. This amounts to $€ 9,375$ net of a $25 \%$ tax that is applied to all lottery winnings. ${ }^{9}$

In addition to the monetary prizes, one of the street-prize winners wins a new BMW. The BMW winner is chosen by randomly selecting one of the winning lottery tickets. BMW winners have the option of receiving the cash value of the BMW in lieu of the car itself. This however involves a substantial tax penalty, since the PCL authority pays the $25 \%$ lottery tax for winners who accept the BMW in kind, but not for those who choose the cash equivalent (about $€ 25,000$ ). Of course, winners also have the option of selling their new BMW, and incurring any associated transactions costs. $^{10}$

\footnotetext{
${ }^{4}$ Thus, conditional on purchasing a ticket, a household's probability of winning the PCL in any given week is approximately equal to one divided by the number of postcodes in the Netherlands (about 430,000).

${ }^{5}$ Videos of recent award broadcasts can be viewed on www.postcodeloterij.nl.

${ }^{6}$ The price increased during our sample period.

${ }^{7}$ The maximum number of tickets available per postcode is capped at 499; this maximum number was not reached in any of the postcodes in our sample.

${ }^{8}$ Eligibility for the large 'jackpot' prize requires households to pay an extra monthly fee (which increased from $€ 1.25$ to $€ 1.50$ during our sample period).
} 


\section{Data}

From September 2003 until July 2006 we sent out written surveys to all addresses in PCL-winning postcodes, six months after the prize was won. Moreover, for each winning postcode, we selected one or more neighboring postcodes as control groups, and sent out the same written survey in those postcodes. In all, we surveyed households in 419 postcodes. Dutch postcodes are much smaller than, for example, U.S. zip codes. An average postcode contains 19 households; the smallest postcode surveyed contained 4 households and the largest 105. Very few Dutch postcodes $(8 / 419=2.1 \%$ in our sample $)$ contain more than 45 households. The survey contains questions on household composition, demographic variables (age, gender, ethnicity, family relationships, marital status), education, labor supply, happiness, car ownership, large expenditures, income, and lottery participation. ${ }^{11}$ For some of the questions respondents provided information on both current behavior (i.e. six months after the prize) and, retrospectively, behavior a year earlier (i.e. six months before the prize).

The selection of nonwinning postcodes was guided by two (opposing) objectives. One is that nonwinners in nonwinning codes should on average live farther away from winners than do nonwinners in winning postal codes. (In our simplest specification, this differential distance identifies social interaction effects.) The other (opposing) objective is that nonwinners in nonwinning codes should not live too far away from winners and nonwinners in winning-postal codes. This is to control as well as possible for any unobserved household characteristics that vary smoothly over space, in case these are not perfectly randomized away by our lottery-based

\footnotetext{
${ }^{9}$ This tax applies to all lottery prizes larger than $€ 454$. It rose to 29 percent on January 1, 2006.

${ }^{10}$ We have observed a small number of ads for BMWs won in the PCL on the Dutch equivalent of eBay.

${ }^{11}$ Facsimiles of the survey instrument, cover letter and written reminders are available at: http://www.econ.ucsb.edu/ pjkuhn/Data/PCL/PCLIndex.html The survey was administered by GfK, a survey research firm.
} 
design. Throughout our discussion, we refer to a winning postcode plus all the nonwinning nearby codes associated with it as a "codegroup”. Most of our analyses will condition on a full set of codegroup fixed effects, although that does not affect our main conclusions.

At the beginning of the survey, households were invited to participate in "scientific research on expenditures and income of Dutch households”, without any reference to social interactions or the PCL. Questions about lottery were asked after the consumption questions, near the end of the survey. Households were offered $€ 7.50$ ( $€ 10.00$ in a small number of cases) to complete the survey. Respondents could choose among a number of charities to receive this fee, or could provide any bank account number (including their own) to which the token was to be credited.

If households did not respond within two weeks, a reminder was sent to households whose phone number was not known. Other nonrespondents were called and asked to complete the questionnaire by telephone with the assistance of a survey agency employee. For the codegroups used in our analysis (i.e. those for which official PCL winner information was provided), the response rate was 32.1 percent in winning postcodes, 33.0 percent in nonwinning codes, and 32.7 percent overall. This overall rate is close to the average response percentage of Statistics Netherlands for similar surveys. Our final sample contains 2011 observations, 510 of which were completed by telephone. ${ }^{12}$

The street addresses of all respondents to our survey are of course known. Identification of social effects is however facilitated if we know the location of all lottery winners in the

\footnotetext{
${ }^{12}$ Since our sampling frame is based on addresses six months after the lottery, our sample would be nonrepresentative if households' propensity to move out of a postcode depends on whether that code (or household) won the PCL. We examined this question directly using the Cadastre and Public Register Agency data on house sales, finding no significant difference in the number of home sales after the PCL prize draw between winning and nonwinning addresses. Detailed results are available from the authors.
} 
winning codes surveyed, including those winners who did not respond to our survey. Street addresses of all winners, plus information on winnings, were provided by the PCL administration for every winning postcode in our survey. From these addresses, we computed two broad types of “proximity to winners” indicators that provide much greater detail than an indicator for whether a household lived in a winning code. The first defines a household's two immediate neighbors as those addresses in the same postcode with house numbers (or unit numbers in the case of multi-unit addresses) immediately below and above its own house number (houses in a postcode all share the same street name); its nearest four neighbors are defined analogously. A second class of proximity measures uses the $(x, y)$ coordinates (in meters) for all addresses in all postcodes in our sample, plus those of all the lottery winners as reported by the PCL administrators. ${ }^{13}$ In this data, addresses within the same building have the same $(x, y)$ coordinates. (Thus, within buildings, our 'neighbor' variable based on the unit number might be a superior measure of proximity to winners than that based on $(x, y)$ coordinates.) One might argue that physical visibility, or social distance is more relevant to peer effects than Euclidian distance. Our choice of the latter is guided by data availability, though we do explore the effects of some social distance indicators later in the paper.

\section{Descriptive Statistics}

Descriptive statistics for the households in our survey sample are presented in Tables 1-3. Table 1 restricts attention to characteristics that are relatively permanent (such as the age and education of the household head(s)), or that refer (retrospectively) to the period before the lottery prize in that household's codegroup was awarded. In addition to providing a statistical portrait of our respondents before the 'treatment' --a set of lottery prizes-- was administered to a subset

\footnotetext{
${ }^{13}$ We obtained the $(x, y)$-coordinates from Bridgis (www.bridgis.nl), which generates its data from municipal land
} 
of the postcodes in our sample, Table 1 provides a test of the exogeneity of this treatment by comparing winning versus nonwinning postcodes. If winning postcodes are truly randomly selected, if the decision to respond to our survey is independent of whether the code was a winning one, and if households' reporting of their own (current and past) consumption behavior is not affected by living in a winning postcode, there should be no statistically signficant differences between the two columns of Table 1.

As Table 1 shows, there is substantial support for the exogeneity of our indicator variable for whether a household lives in a winning code: only 2 of 23 comparisons - involving the share of households that are single-headed and spending on vacations-- are statistically significant at the 10 percent level. Overall, the message of Table 1 is one of consistency with random selection of winning codes and absence of response or recall bias. On those dimensions for which comparable information is available, the statistics in Table 1 are also consistent with national means from Statistics Netherlands. For example, national mean household size in 2005 was 2.30, and 65.5 percent of households were two-headed, compared with 2.31 and 64.9 among respondents to our survey. The average age of the Dutch population in 2005 was 38.5; if we add non-household heads to the sample in Table 1, the mean age in our sample is 38.4. ${ }^{14}$

Table 2 presents descriptive statistics on awareness of and participation in the post-code lottery, and on amounts won, both by survey respondents and their 'neighbors'. Awareness by residents of the fact that their postcode won the PCL is high, even six months after the win. For example, 87 percent of respondents in winning codes (including both winning and nonwinning households) say they remember that a PCL Street Prize was awarded in that code 6 months after 
the fact. 53 percent of households in winning codes say they recall the number of households who won, and 25 percent report house numbers of at least some of these winners when asked to do so. Such high awareness levels seem likely to be conducive to the existence of social effects in this context. As we would expect, awareness of the lottery is considerably lower in neighboring, nonwinning codes.

The next two sections of Table 2 provide information on PCL ticket ownership and winnings, both conditional on PCL participation and not. The average PCL participant held about 1.8 tickets; the average amount won was $€ 18,596$. After the $25 \%$ lottery tax, these winnings correspond to about $€ 13,947$, or about 7 months of post-tax income for a typical Dutch household. 11.2 percent of ticket owners in winning codes won a BMW. Adding in the expected value of this BMW (we value the BMW at $€ 25,000$ ), the average amount won by a household in the PCL rises to $€ 13,947+.112(€ 25,000)=€ 16,047$, or about 8 months of income for an average family in our sample. ${ }^{15}$ About 32 percent of surveyed households in winning codes reported owning at least one PCL ticket; this figure is lower in nonwinning codes, possibly because households in those codes are less likely to recall owning a ticket. ${ }^{16}$

The remainder of Table 2 presents a variety of indicators of the amount of lottery winnings that took place in the geographical vicinity of a typical household in our data. According to our data, just over half (52\%) of households living in winning postcodes had an

\footnotetext{
${ }^{14}$ Source: authors' extracts from http://statline.cbs.nl. Comparable education information is not easily calculated because the national mean refers to all persons aged 15-64, and our survey does not collect education information for non-household heads.

${ }^{15}$ The BMW awarded in the PCL is a model 116i. Between 2005 and 2007 we found advertised new prices for this vehicle ranging from $€ 25,400$ to $€ 28,500$. For reasons that become apparent later in the paper, we apply the $25 \%$ lottery tax to the BMW as well as to the cash winnings in this calculation.

${ }^{16}$ Another possible reason is that, by construction, winning codes must contain at least one household that purchased a PCL ticket; nonwinning codes do not have so satisfy this criterion to be in our sample. To see if this might affect our results, we replicated most of our estimates of social effects after excluding postcodes containing fewer than 19 households from our sample (if the true share of households buying tickets is . 25 and buyers are independently
} 
immediate neighbor who won a PCL prize. ${ }^{17}$ In winning codes, the average amount won by a household's two immediate neighbors was €13,392. For an average household living in a winning code, 2.46 winning households lived in the same building (and were thus assigned the same $(x, y)$ location). About 3 winning households lived within 25 meters of an average survey household; 7 within 100 meters. A typical winning postcode contained 8.5 winning households, and the average total amount won in a winning postcode was $€ 217,980$. Finally, 8.1 percent of households living in winning postcodes lived directly next door to a BMW winner; 37 percent lived within 25 meters of a BMW winner. As for all rows of Table 2, this share was statistically highly distinct from the share in nonwinning codes.

Table 3 presents descriptive statistics for a long list of outcome variables that might have been affected either by winning the lottery, or by living close to lottery winners. Since Table 3 does not yet distinguish between PCL participants and nonparticipants, it will not distinguish between own and social effects of a PCL win; it simply provides a first look at whether large effects of either type are likely to be present. According to Table 3, no statistically significant post-lottery differences in consumption between winning and nonwinning codes are found for monthly expenditures on food at home, food away from home, transportation, other monthly items, or total monthly expenditures. ${ }^{18}$ Insignificant differences are also found for happiness, PCL participation at the survey date, and for several indicators of major expenditures that refer to the entire six-month period between the lottery and survey dates: whether the household

distributed over space, this reduces the probability that a code will contain zero buyers to less than .004). The estimated social effects were, if anything, slightly stronger and more significant.

${ }^{17}$ In principle, a household in (but at the boundary of) a nonwinning code could live next door to a PCL winner; our method of identifying neighbors will not capture these households. Households living in nonwinning codes but close to winners will, however, be included in our Euclidean-distance-based measures of proximity to winners.

${ }^{18}$ All of these consumption items are asked in the sixth month after winning the survey and refer to the previous month. We also examined differences in post-lottery labor market behavior, including whether household heads work and their hours of work. No effects were found, either in the Table 3 specifications or the regression-based analyses undertaken later in this paper. 
initiated major interior home renovations, total expenditures on vacations, and purchases of durable goods (excluding automobiles). ${ }^{19}$ In contrast, households living in winning codes were twice as likely (3.0 versus 1.5 percent) to initiate major exterior home renovations during this period; this difference is statistically significant.

Table 3 also shows a number of significant differences in car ownership between winning and nonwinning codes six months after the lottery date. In particular, compared to nonwinning codes, households in winning codes are more likely to have acquired a new car in the six months since the lottery; they also own more cars (and more car efficiency units ${ }^{20}$ ) at the survey date. Their main car is on average nine months newer. Of course, all of these outcomes could simply be mechanical consequences of the fact that cars (specifically BMWs) were a prize in the PCL. Table 3 addresses this issue in two ways: first, we exclude all BMW winners from the sample; and second, we look specifically at BMW ownership six months after the lottery. In the first approach, we find that all the above indicators of car consumption remain higher in winning codes even when BMW winners are excluded from the sample (in fact the statistics are almost identical). Thus the households who won only cash (and/or their nonwinning neighbors) appear to be increasing their car consumption after a lottery win. ${ }^{21}$ Second, the results for BMW ownership are both clear and, perhaps, surprising: six months after the lottery, households in winning codes are statistically no more likely to own a BMW than households in nonwinning codes. Thus it appears that most BMW winners either elected to receive the cash prize in lieu of

\footnotetext{
${ }^{19}$ The 'occasional' expenditure amounts (including vacations and durables) in Table 3 are not directly comparable to the pre-lottery levels in Table 1 because the latter refer to the 18-month period preceding the lottery date in one's codegroup.

20 A new car is defined as one unit; older cars are depreciated at 15 percent per year. This is the average depreciation rate over the first 11 years of a car's life in the Netherlands, which we calculated from historical purchase prices and current resale values obtained at from www.autoweek.nl. The sample of vehicles used was all cars owned by the households in the Table 11 sample.

${ }^{21}$ In a nonexperimental study, Grinblatt et al (2004) find correlations between the models of cars purchased by neighbors in Finland, but conclude that this is not the result of imitative behavior.
} 
the BMW (thus incurring a 25\% tax penalty), or sold their BMWs shortly after they received them, presumably incurring some transactions costs in the process (we cannot distinguish these with our data).

To explore this result further, Table 4 provides more details on post-PCL BMW ownership; it shows that 26 BMW winners responded to our survey. Of these, only four still owned a BMW at the survey date, six months after the lottery. ${ }^{22}$ While four BMWs is more than one would expect in a random sample of 26 Dutch households, overall the behavior of the BMW winners in our sample is remarkably consistent with simple models of in-kind transfers (see for example Moffitt 1984, 1989): whenever a gift in kind would induce a suboptimal consumption mix (as a new BMW is likely to do for the vast majority of Dutch households), that gift should, if possible, be converted into its cash equivalent and spent on other items (or, of course, saved).

\section{Own and Social Effects of the PCL: Simple Tests}

As noted, a clean and simple way to detect social effects of the postcode lottery is to examine the post-lottery consumption behavior of the households in our survey who did not participate in the lottery. None of these households won any money; thus they were not directly affected by the lottery. However a subset of these households was randomly exposed to the treatment of having its postcode-mates win significant amounts of money: an average winning postcode contained 8.5 (out of 19) winning households who won a total of $€ 217,980$. Thus, as long as a household's own postcode contains, on average, more members of its reference group than live in nearby 'control' codes, a simple comparison of the behavior of PCL nonparticipants

\footnotetext{
${ }^{22}$ One possible concern with this result is that our survey collects information on a maximum of two cars per household. Could a significant number of BMW winners still own a BMW as their third, or higher-order car? For 18 of the 26 BMW winners, this is impossible, since they own either zero or one car at the survey date. Of the remaining 8 households, two report owning a BMW at the survey date. Thus at the very most, 6 BMWs could be
} 
between winning and nonwinning codes will reveal the presence of social consumption effects. The same comparison for participants, in contrast, identifies a combination of own and social effects, since winners receive shocks to both their own and their neighbors' income when their postcode is randomly selected by the PCL.

Table 5 provides the above comparisons for essentially all the household consumption measures available in our survey. Column 1 reports the mean consumption difference between PCL ticket holders living in winning versus nonwinning codes; column 3 reports the same difference for households who did not own any PCL tickets. These differences and their standard errors are calculated from a regression of consumption on a dummy variable for residence in a winning code. Columns 2 and 4 add a full set of codegroup fixed effects to those regressions. If winning postcodes are indeed randomly chosen and if survey response patterns are not affected by a PCL win, postcode fixed effects should not be necessary to eliminate bias. However, if unobserved household characteristics vary smoothly over geographical space, codegroup fixed effects should correct for any response or randomization bias. For some of our outcome variables, we collected retrospective (i.e. pre-lottery) as well as current information. For those cases, Table 5 presents comparisons of within-household consumption changes as well as post-lottery levels. ${ }^{23}$ These differenced measures should also eliminate simple forms of randomization or response bias; on the other hand (as is well known) differencing typically adds noise, making it harder to detect an effect. Finally, because some expenditure distributions

missing from our sample for this reason. Since owning more than two cars is very rare in the Netherlands, the true number is likely much smaller.

${ }^{23}$ Unfortunately, due to some flaws in survey design, our data do not allow us to analyze changes in car ownership before and after the lottery. These flaws include the fact that the survey did not ask any retrospective questions about car ownership of households who owned no cars at the survey date, and the fact that we do not know when a household disposed of the cars it owned prior to the survey. 
(especially those for vacations and durables) both contain a substantial number of zeros and have a long right tail, we also include specifications based on the square root of expenditures.

Turning first to social effects (in columns 3 and 4), with just a handful of apparently random exceptions, the only consumption item for which Table 5 indicates any significant social effects is automobiles. Specifically, nonparticipating households are more likely to have acquired a car within the past six months if they live in a winning postcode. ${ }^{24}$ Among households who did not participate in the PCL at the lottery date, those who live in winning codes are less likely to play the PCL six months later. Witnessing one's postcode-mates win the PCL does not make nonwinning households any less happy six months after the fact.

Turning now to the behavior of PCL participants (i.e. households who owned at least one PCL ticket at the time of the win in their codegroup), we see a few more significant differences in consumption between winning and nonwinning codes. For example, six months after the win, PCL winners' main car is newer than nonwinners', and the household owns a larger total number of car efficiency units. Both of these effects are robust to excluding BMW winners from the sample, so they are not a mechanical result of the BMW prizes. (To eliminate such mechanical effects, BMW winners are excluded from all the car consumption regressions in the remainder of the paper.) These car consumption effects are also somewhat robust to adding codegroup fixed effects. Among other consumption measures, effects are most consistently detected for food away from home and durables expenditures (excluding cars). Some indication of a possible effect is also present for food at home, total monthly outlays, and vacations, though these are present in a minority of specifications and may be due to sampling error. Finally, PCL winners are more likely than nonwinners to donate the fee they receive for completing our survey to

\footnotetext{
${ }^{24}$ We also see a 'perverse' negative social effect on BMW ownership, but as noted BMWs are very rare in this population.
} 
charity.

In sum, Table 5 provides preliminary evidence of social consumption effects for only one type of good: cars. Perhaps this is not surprising since (with the possible exception of exterior home renovations) cars are probably the most highly visible consumption item to one's residential neighbors. Table 5 also shows that PCL-participating households whose postcode was selected as a winner have higher car consumption, in addition to spending more on non-car durables and food away from home. Technically, these differences estimate the sum of own- and social effects affecting winners in winning codes; however since most of our estimated social effects are zero it seems likely that these differences represent responses to own income shocks.

\section{A Statistical Model}

In the PCL, as in all lotteries, the variation in a household's winnings (and in our case in its neighbors' winnings) is driven by two distinct factors, only one of which (the selection of a household's postcode by the lottery authorities) is strictly exogenous. The remaining factor, of course, is the number of lottery tickets purchased by the household; included in this category is the decision to buy any lottery tickets (i.e. to participate in the PCL) at all. This section describes a simple statistical model whose goal is to isolate the effects of the exogenous component of lottery winnings on household consumption.

Let a household's consumption, $C_{i}$, depend on its own PCL winnings $\left(W_{i}^{O}\right)$ and its neighbors' PCL winnings $\left(W_{i}^{N}\right)$ as follows:

$$
C_{i}=\alpha+\beta W_{i}^{O}+\gamma W_{i}^{N}+\theta X_{i}+g T_{i}^{O}+h T_{i}^{N}+e_{i}
$$

where $X_{i}$ includes measurable determinants of income and preferences (including own nonlottery income, for example), $T_{i}^{O}$ is the total number of PCL tickets owned by the household, $T_{i}^{N}$ 
is the number of tickets owned by the household's reference group, and $u_{i}$ is iid. ${ }^{25}$ We include $T_{i}^{O}$ to capture unobserved household tastes or constraints that may affect its consumption of all items, including lottery purchases (for example, risk-loving households may buy more PCL tickets, and will also have different consumption patterns for other items than risk-averse households). We include $T_{i}^{N}$ to capture possible correlation of such unobserved tastes or constraints within neighborhoods. For example, if immigrant households disproportionately tend to live together (even within postcodes), and immigrants tend to share common unobserved tastes or constraints, then a household's own consumption may be correlated with the number of lottery tickets purchased by its neighbors. ${ }^{26}$

Since each winning lottery ticket pays 12.5 (thousand) euro,

$$
\begin{aligned}
& W_{i}^{O}=12.5 * T_{i}^{O} * \delta_{i}, \quad \text { and } \\
& W_{i}^{N}=12.5 * T_{i}^{N} * \delta_{i} .
\end{aligned}
$$

where $\delta_{i}$ is an indicator for living in a winning postcode. ${ }^{27}$ Since winning postcodes are randomly selected by the PCL authorities, $\delta_{i}$ is orthogonal to $T_{i}^{O}, T_{i}^{N}, X_{i}$ and $u_{i}$.

\footnotetext{
${ }^{25}$ An alternative specification of social effects, of course, has own consumption depend not on neighbors' income but on neighbors' consumption. In this paper we focus on the effects of shocks to neighbors' incomes, for three reasons. Most obviously, shocks to neighbors' income are exogenous in our context; changes in consumption are not. Second, households' consumption is highly multidimensional, which makes it far from clear how to best model consumption interdependencies. (Does my propensity to buy a new car depend on your purchase of a specific model and quality of car, on your decision to purchase any car, on the fact that you recently made a visible purchase of any kind, or simply on the fact that you won some money?). Third (and related) effects of neighbors' consumption and income on a household's own consumption are, in general, not separately identified by a neighbor's-income instrument. This is demonstrated in Appendix 2.

${ }^{26}$ The simple model estimated in Table 5 can, of course be seen as a special case of model (1), specifically one where $T_{i}^{O}$ is simply an indicator for holding a positive number of PCL tickets; own winnings, $W_{i}^{O}$, are measured by $T_{i}^{O} * \delta_{i}$ (see equation 2); neighbors' winnings, $W_{i}^{N}$, are measured by $\delta_{i}$; and $\theta=h=0$.

${ }^{27}$ To simplify notation, equation 3 does not include the BMW in winnings. The BMW of course adds an additional random component to winnings, which is desirable from an experimental point of view. Like cash, however, it can only be won if the household (endogenously) chooses to participate in the PCL. Equation 3 also implicitly assumes that households living in nonwinning codes have no winning households in their peer group. This is easily generalized; in fact a number of our empirical definitions of peer groups (indeed all those based on Euclidean distance) include households in winning codes that are geographically close to households in nonwinning codes in the latter households' consumption reference groups.
} 
Equations (1) - (3) imply the following. First, suppose unobserved household tastes and income do not vary systematically with the number of lottery tickets purchased, i.e. that $g=h=$ 0. Then OLS applied to equation (1) yields unbiased estimates of the own and social effects of unexpected income shocks, $\beta$ and $\gamma$. In fact, our estimates of $\beta$ and $\gamma$ are unbiased even if we exclude all measured observable characteristics, $X$, from the regression; their only role would be to improve efficiency. This is because the variation in own and neighbors' winnings is generated only by variation that is either by construction $\left(\delta_{i}\right)$ or by assumption $\left(T_{i}^{O}\right.$ and $\left.T_{i}^{N}\right)$ uncorrelated with the error term.

Of course we cannot be sure that $g=h=0$, which in general leads to bias in (1). To accommodate $g \neq 0$, we have access to a simple solution-we simply include controls for the number of PCL tickets held by the household at the time of the win, $T_{i}^{O}$. In fact, we include in all of our regressions a quadratic in number of tickets purchased plus a fixed effect for purchasing a positive number of tickets (i.e. a fixed effect on consumption of participating in the PCL). ${ }^{28}$ Unfortunately, we do not have comparable measures of $T_{i}^{N}$, for two reasons: (a) we do not know ticket purchases for those neighbors of our respondents who did not respond to our survey, and (b) we do not know, ex ante, which households (or which particular weighted sum of households) constitute a household’s reference group.

In the following sections we address the above data limitation in several ways. First, we can test for the exogeneity of all of our measures of a houshold's neighbors' winnings by asking whether these measures are correlated with a households' observable characteristics. In almost all cases, we find that they are not. Second, as in Section 5, we have access to codegroup fixed effects and (for some of our consumption measures) time-differencing within households. Third, especially for some definitions of a household's reference group, we are able to generate 
estimates of the number of PCL tickets purchased by that group using our own survey data; we report the results of these exercises near the end of the Section 8.

Fourth, and finally, we can use the strict exogeneity of $\delta_{i}$ to rewrite (1) as:

$C_{i}=\left[\alpha+h \bar{T}^{N}\right]+\beta W_{i}^{O}+g T_{i}^{O}+\left[\gamma \bar{W}^{N}\right] \delta_{i}+\theta X_{i}+\left[h u_{i}+12.5 \gamma \delta_{i} u_{i}+e_{i}\right]$

where $\bar{T}^{N}$ is the (unconditional) mean of the number of PCL tickets purchased by a household's reference group in our sample, $u_{i}=T_{i}^{N}-\bar{T}^{N}$, and (by implication) $\bar{W}^{N}=12.5 \bar{T}^{N}$ (i.e. the the mean amount won by a household's peer group if its code is selected to win the PCL). Equation (4) simply regresses consumption on own winnings, own ticket purchases, and a dummy for whether the household lives in a winning postcode. While (4) has a heteroskedastic error term, OLS still yields unbiased estimates of the own effect of lottery winnings, $\beta$, and of the social effect, $\gamma$, where the latter is scaled by the mean amount won by a household's peers if its code wins the PCL. Unless an average household has zero peers living in its neighborhood, or those peers purchase a mean of zero lottery tickets, this allows for hypothesis tests on $\gamma=0$ even in the absence of data on $T_{i}^{N}$. Intuitively, (4) identifies the own effect of lottery winnings from the interaction of living in a winning code with the number of lottery tickets owned. According to (4), any additional effects of living in a winning code must be due to social effects.

\section{Results-- Own Effects of Lottery Winnings}

In this section we report the results of estimating equations (1) and (4) for the parameter $\beta$, i.e. the own effects of lottery winnings. As discussed above, our identification strategy is based on the notion that, conditional on the number of lottery tickets purchased by a household (including zero), income shocks are randomly assigned by the random event of a household's

\footnotetext{
${ }^{28}$ The results are very similar if we include a fixed effect for each integer number of tickets purchased.
} 
postcode being drawn as a winner. To verify this, Appendix Table A1 reports the results of a set of "exogeneity checks" for the variation in winnings we will use to identify the own effects of winning the lottery. Specifically, the coefficients reported are from a regression of total individual winnings (these include the monetary equivalent of any BMWs won, and equal zero for nonwinners) on an indicator for whether the household lived in a winning postcode. Included in all regressions are a fixed effect for lottery participation, and a quadratic in the number of tickets purchased. For the most part, the results in Table A1 are encouraging: virtually all observable, pre-lottery characteristics are uncorrelated with this measure of own winnings. Exceptions are food away from home and total pre-lottery income (the latter significant at only 10\%); both correlations become insignificant in the presence of codegroup fixed effects. Overall, it appears that, conditional on the number of tickets purchased, lottery winnings are essentially randomly assigned among our respondents.

Our estimated effects of lottery income on a household's own consumption, based on equation 4, are reported in Table 6. Coefficients in the Table represent the effects of winning $€ 10,000$ pre tax (slightly less than the winnings from a single lottery ticket) on the outcome variable in question. All regressions include a fixed effect for owning any PCL tickets, a quadratic for the number of tickets purchased, and a fixed effect for residence in a winning postcode. As discussed, all the variation in the lottery winnings variable is therefore induced by the random draw of whether one's postcode won the lottery. This notion is confirmed by the fact that our estimates of own effects are very similar in all three regression specifications shown in that Table: neither adding codegroup fixed effects, nor adding controls for demographic characteristics -including the level of household income before the lottery date- has much effect on either the estimated coefficients or their standard errors. 
According to Table 6, winning the PCL has no detectable effects on several expenditure categories, including food at home, transportation expenditures, other monthly expenditures, and total monthly expenditures. As in Table 5, effects are however detected on certain aspects of car consumption, in particular the age of the household's main car six months after the lottery date and the number of 'car efficiency units' owned at that time. In terms of magnitudes, winning $€ 10,000$ appears to reduce the average age of a household's main car by about .4 years. Since the average age of a main car is about 7 years, this is about a six percent decline. Another detectable effect of winning the lottery is on food away from home: unexpectedly winning a lump sum of $€ 10,000$ appears to raise eating out by about $€ 18$ per month, six months after the win. In one specification, we see marginally significant effects of own winnings on home renovations. We also see strong and robust effects of lottery winnings on durables expenditures, as we might expect from some versions of the life cycle consumption model (e.g. Browning and Crossley 2004).

Unexpectedly winning the PCL (which, as noted, amounts to about 8 months of income for an average household) has no detectable effects on a household’s reported happiness: In both the level and differenced specifications, the estimated coefficients are always statistically insignificant. Further, the estimated coefficients are very small, relative to the standard deviation of current happiness (1.75) and of year-to-year changes in happiness (1.33) in our sample. In the fixed-effects specification, we can rule out (with 95\% confidence) effects greater than .07 of a standard deviation (in either direction) on either the level or the change in happiness. Participation in the postcode lottery at the survey date (six months after a win in one’s neighborhood) is positively related to the amount won in the lottery. In contrast to the simple 
results in Table 5, greater lottery winnings do not raise the likelihood that a household will donate its fee for completing our survey to charity.

In order to shed additional light on the estimated effects of lottery winnings in Table 6, Table 7 reproduces the lottery effects from columns 5 and 6 of Table 6, and compares them to the coefficients on the household's own pre-lottery income, which was included in the same regression. Compared to lottery winnings -which are both temporary and unexpected--, crosssectional income differences should have a substantially larger permanent component. According to the life-cycle model of consumption, they should therefore be more strongly related to current expenditures than are lottery winnings, at least for nondurables. Are they?

In Table 7, some expenditure categories do appear to respond more to total income than to lottery income, for example food at home, 'other' monthly expenditures, vacations, and the propensity to donate the survey fee to charity (though some of these differences are clearly not statistically significant). For other expenditure categories, however, consumption appears to be just as sensitive, if not more sensitive, to lottery income as it is to total income. These include the age of the household's main car, total car consumption, food away from home, and durables expenditures. For car and durables, this high relative sensitivity to lottery winnings could simply reflect consumption smoothing. Our result for food away from home, however, is harder to reconcile with a simple life-cycle model. ${ }^{29,30}$

\footnotetext{
${ }^{29}$ According to our estimates, a one-time, $€ 10,000$ lottery prize raises expenditures on food away from home by about 18 percent, six months after the prize. The average age of our respondents is 50, and their average annual post-tax household income is $€ 23,000$. Using a life expectancy of 75 and a discount rate of 5 percent, the present value of their remaining lifetime income is about $€ 330,000$. Thus a prize of $€ 10,000$ corresponds to about a 3 percent increase in lifetime income. Unless eating out is an extreme luxury good, an $18 \%$ increase in response to this appears very unlikely in a life cycle model.

${ }^{30}$ Two other implications of the life cycle model are that the effects of lottery winnings on expenditures should be greater for older households, and for lower-income households, since in both these cases a 10,000-euro PCL prize has a larger proportional effect on the present value of lifetime income. To explore these predictions we reestimated Table 6 separately for low- and high-education groups, and for households whose heads are above and below the median age of 50 . While interesting, the results may reveal more about the distinction between luxuries
} 
The one outcome on which lottery and nonlottery income have the most dramatically different effects in Table 7 is happiness. Indeed, in contrast to our results for lottery winnings, and consistent with both Easterlin (1974) and Stevenson-Wolfers (2008), higher total income is very strongly associated with happiness in a cross-section of households. One interpretation of these contrasting results is that the six-month lag we chose between the PCL win and the survey date is too long: lottery winnings could affect own happiness, but the effects are very transitory, as argued by both Easterlin and Kahneman et al (2006). Alternatively, the results of Gardner and Oswald (2007) suggest that six months might be too short: In their analysis of Britons who receive lottery wins between $£ 1000$ and $£ 200,000$ they find that in the year a prize is won, mental stress goes up, while in subsequent years lottery winners show less stress than nonwinners. That said, absence of mental stress and happiness are not the same thing. Finally, it is possible that happiness is simply more linked to long-run personal income than short-run fluctuations, both because permanent income differences enable the household to take more happiness-improving actions, and perhaps because long-term income differences are more likely to be seen as “earned” and thus legitimate. ${ }^{31}$

\section{Results-Social Effects of Lottery Winnings}

In this section we report estimates of $\gamma \bar{W}^{N}$ in equation (4), and of $\gamma$ in equation (1) for a variety of explicit specifications of households' consumption peer group. In fact, we estimated social effects using all the indicators of neighbors' winnings summarized in Table 2; only a

and necessities and age-related variation in a household's consumption priorities than the life cycle hypothesis per $s e$ : low-education households seem to spend more lottery winnings on cars, and less on vacations than higheducation households. Young households also spend more of their lottery winnings on cars than older households, but older households' durables consumption is much more responsive to lottery income than younger households'.

${ }^{31}$ Another interpretation of our own-happiness results is of course the possibility that the cross-sectional correlation between income and happiness is driven by reverse causation (happier people are more successful in the labor 
subset of those results are reported here. ${ }^{32}$ As noted, these alternative measures of neighbors' winnings are randomly assigned only if we can condition on the number of tickets purchased by whomever we define as the household's neighbors. Since that is not possible for most of the measures we use, we first conduct a set of simple 'exogeneity checks' of the variation in neighbors' winnings we use to identify social effects, parallel to what we did in Table A1 for own winnings.

Specifically, Appendix Table A2 examines the variation in the following indicators of a household's neighbors' winnings: whether the household lives in a winning postcode, the number of winning households in its postcode, the total amount won within 25 meters, and whether one of the household's two immediate neighbors won a PCL prize. The coefficients reported there are the estimated "effects" of fixed household characteristics on indicators of neighbors’ winnings, with controls for PCL participation and a quadratic in number of tickets bought. For the most part, these tests are reassuring as well. Some significant coefficients do appear, but with one exception they do not suggest a consistent pattern. In the specification with codegroup effects (but not without), it appears that households who live close to winners tend on average to be poorer (pre-lottery) than other households. This raises the possibility that our estimates of social effects that do not control for pre-lottery household income are biased downwards (for normal goods); in practice our estimates of social effects are however very similar whether or not we control for codegroup effects, or the vector of demographic controls $(X)$, which includes household income.

market). This interpretation would, however, be at odds with Stevenson and Wolfers' recent claim that economic growth promotes happiness.

32 Other possible comparison groups that cannot be captured in our data include the workplace, family and voluntary associations including churches, etc. While we cannot examine these comparisons directly, we defend our (datadriven) focus on neighborhoods by noting that (a) awareness that one's neighbors won the PCL is very high (see Table 2), and (b) at least some consumption items, such as cars and exterior home renovations, are highly visible to neighbors, even when those neighbors are not necessarily closely connected socially. 
Our estimates of social effects, using all four alternative indicators of neighbors' winnings in Table A2, are presented in Table 8. Columns (1) and (2) present estimates of $\gamma \bar{W}^{N}$, taken from the regressions underlying columns 5 and 6 in Table 6 . The remaining columns replace the dummy for residence in a winning code in those regressions by alternative measures of neighbors' winnings. As already noted, all of these regressions control for the household's own PCL winnings, a fixed effect for whether it purchased any PCL tickets, a quadratic in the number of tickets purchased, and a full set of codegroup fixed effects, and a vector of demographic characteristics including prelottery income.

One pattern is clearly evident in Table 8: for the vast majority of consumption items, essentially no social effects on consumption are detected. In particular, with a few apparently random exceptions, Table 8's indicators of neighbors' lottery winnings have no statistically significant effects on any category of monthly expenditures, on vacations, durables, or happiness. A natural question to ask for these outcomes, of course, is whether the insignificant coefficients indicate truly small social effects, or simply large standard errors on our estimates. To better understand these magnitudes, we focus on column 1 of Table 8; by construction these coefficients give the effect on own consumption of seeing one's postcode-mates win a total of $€ 217,980$. The estimated effect of a neighborhood win of this magnitude on a household's own monthly eating out is $€-10.55$; the $95 \%$ confidence interval surrounding it runs from $€-35.66$ to $€ 14.57$. Coincidentally, the upper bound of this confidence interval is is roughly the same as our (relatively precise) point estimate of the effect of the household winning €10,000 itself in Table 6 (€17.49). This upper bound on social effects is also small when compared to the typical year-toyear variation in eating out in our sample of Dutch households; in particular it is about one-fifth of the standard deviation of year-to-year changes in expenditures on food away from home 
(€78).

Similar calculations apply to most of the other components of monthly expenditures, and to vacation and durable spending in Table 8; in general, if a shock to neighbors' incomes of the size generated by the PCL had large effects on any of these outcomes relative to the outcome's typical year-to-year variation, it would have been detected by these regressions. Because it has received considerable attention in recent literature, we discuss only one additional outcome in detail here: happiness. According to column 1 of Table 8, the effect of living in a winning postcode (but not winning oneself) on a household's happinessis is -.0515, with a 95\% confidence interval ranging from -.205 to +.102. The lower bound of this confidence interval amounts to a reduction in happiness of about one sixth of the standard deviation of year-to-year changes in happiness in our sample. Our 'social' results for happiness contrast with Luttmer's (2005), though his refer to effects of neighbors' earnings on happiness, which have a bigger permanent component than lottery winnings, and neighbors’ earnings are not randomly assigned in his analysis. The absence of an effect of exogenous changes in neighbors' incomes on own happiness in our data also supports Stevenson and Wolfers’ (2008) conclusions from a large sample of within- and between-country data, though that analysis is not able to consider the effects of strictly exogenous changes in peers’ incomes.

In contrast to the above results, Table 8 provides quite robust evidence of two social effects related to the PCL and to our survey instrument respectively. First, in contrast to lottery winnings' own effects on PCL participation, social effects of lottery winnings in one's neighborhood on current PCL participation are robustly negative. In other words, lottery nonparticipants who are surrounded by households who won the PCL six months ago are less likely to play the PCL today than nonparticipants who are not surrounded by winners. To the 
extent that the 'regret-minimization' hypothesis associated with the PCL predicts that nonplayers will be induced to start playing when they see others win around them, this finding contradicts that hypothesis. ${ }^{33}$ Second, living in close proximity to winners increases the likelihood that the respondent will donate his/her survey fee to charity (even though we detect no own effects of winning on this outcome). ${ }^{34}$

Finally, we note that Table 8 suggests the presence of social effects for two aspects of consumption that are likely to be visible to one's neighbors: exterior home renovations and cars. The evidence for the former confirms the simple differences in means found in Table 3, but is confined to one regression specification. The latter (for cars) is more robust. In particular, significant effects are found on at least one indicator of car consumption for three of our four measures of neighbors' winnings. These estimates of social effects on car consumption are substantial in size, though the standard errors are high as well. For example, having an immediate neighbor win the PCL raises the probability that a household will buy a new car by just under 5 percentage points, reduces the mean age of its main car at the survey date by about half a year (about a 7 percent decline), and raises the total number of car efficiency units it possesses by .021 (about a 5 percent increase). Each of these estimated effects is larger in magnitude than the estimated effects of winning $€ 10,000$ itself, in Table 6.

In sum, with the exception of car consumption and (possibly) exterior home renovations, and of two items closely associated with our survey and the PCL itself (current PCL participation and the disposition of the survey fee), Table 8 allows us to quite confidently rule out large social effects of the lottery on consumption patterns, and on happiness. Perhaps this is not surprising

\footnotetext{
${ }^{33}$ Superficially, it is more consistent with a "lightning never strikes (the same postcode) twice" misperception, however we note from Table 6 that that the opposite misperception seems to apply to PCL participants.
} 
given the fact that, consistent with the life-cycle hypothesis, households' own consumption choices are hardly affected by a sizable one-time lottery win. In the remainder of this section we conduct a more detailed analysis of social effects of the PCL on car consumption (and to a lesser extent on exterior home renovations). In part this is because Table 8 suggests these effects might be present. In addition, there are two good reasons for expecting stronger social effects here: of all our consumption indicators, cars and exterior renovations are (a) likely to be the most visible to one's residential neighbors, and (b) durable. Unlike an expensive party or vacation which only happens once, your neighbors are continuously reminded of your new car or windows every day after they have been purchased.

To explore the social effects of lottery winnings on car consumption further, Table 9 presents estimated effects of a much larger variety of neighbors’ winnings measures on our four indicators of car consumption. The specification is identical to Table 8; for convenience we reproduce Table 8's estimates there as well. Several patterns are evident. First, none of the indicators of neighbors’ winnings based on Euclidean distance have significant effects on any measure of car consumption. We conjecture that these measures do not discriminate sufficiently among the very large share (81 percent) of Dutch households who live in multi-unit dwellings. ${ }^{35}$ Second, significant social effects are never observed for our 'number of cars’ indicator; given the parking constraints facing many Dutch households, it seems likely that any lottery-induced car consumption takes the form of quality rather than quantity. Finally, while we detect a number of effects at the level of the entire postcode, statistically significant social effects are most consistently observed for measures of neighbors' winnings based on a household's two or

\footnotetext{
${ }^{34}$ Since the main purpose of the PCL is to raise funds for charity, it may be that participants view their participation as a charitable contribution. It has been suggested that the publicity associated with a local win induces nonparticipants to make charitable donations as well, for example via their survey fee.
} 
four nearest neighbors. This suggests that social effects on car consumption are highly localized. As in Table 8, both the point estimates and confidence intervals surrounding Table 9's estimated social effects are large. For example, raising the share of households in one's postcode who won the PCL from zero to one is estimated to reduce the age of one's main car by about 1.5 years (from a mean of 7 years). However, the 95\% confidence interval ranges from a decline of .34 years to one of 2.73 years.

If the social effects identified in Table 9 are genuine, they should also be visible in simple comparisons that take the best possible advantage of the exogenous assignment of lottery winnings in our sample. Focusing, as suggested by Table 9, on a household's two and four nearest neighbors, Table 10 restricts attention to PCL non-participants (like the simple comparison in Table 5, this holds own winnings constant) and presents simple means of our four car consumption indicators for three subgroups: those who live in nonwinning codes, those who live in winning codes but do not live next door to a PCL winner (these households will be affected by any postcode-wide social effects on car consumption), and those who do live next door to a PCL winner (who are affected both by post-code-wide social effects and those stemming from their immediate neighbors). In addition to our four car consumption measures, Row 2 of Table 10 asks whether a household acquired one of its current vehicles in the six months before (rather than after) the lottery; it is included as a falsification test. Clearly, all indicators of car consumption in Table 10 except row two are largest for households living next door to PCL winners. To the extent that, within postcodes, living next door to a PCL ticket holder is exogenous, Table 10 provides convincing evidence that (a) social effects of winning the PCL do exist, but (b) they are highly localized, restricted in large part to a household's nearest

\footnotetext{
${ }^{35}$ Thoughout this paper, households are defined as living in a multi-unit dwelling if their address shares a Bridgis $(x, y)$ location with at least one other address.
} 
neighbors. $^{36}$

Table 11 extends the analysis of Table 10 by addressing the possible endogeneity of living within one or two doors of a PCL winner. As already discussed, if unobserved household characteristics are correlated within postcodes at the extremely detailed level of next-door neighbors, households who live next door to ticket buyers may differ from other households in unobserved ways that could contaminate Table 10's estimates. To address this concern, Table 11 uses information from our survey to construct an indicator of whether a household lives next door to a PCL buyer. As already noted, this indicator is necessarily incomplete because it is survey-derived. In particular, to be in the sample for Panel A of Table 11, a survey household must have had at least one of its two nearest neighbors respond to the PCL survey and at least one of those neighbors must report holding a PCL ticket in our survey. Thus, by construction, all the households in the Table 11 sample live next door to a PCL ticket owner; the only variation in whether the neighbors of the Table 11 households won is generated by the random choice of their postcode as winning or not in the PCL. As the Table makes clear, all indicators of current car consumption with the exception of the ‘placebo' measure in row 2 are higher for those households who were exposed to the treatment of having a next-door neighbor win the PCL. Sample sizes are small, however, and only one of the comparisons is statistically significant (and that at $10 \%)$. Both sample size and statistical significance rise if we define the 'treatment' as having at least one of one's four nearest neighbors win the PCL.

\footnotetext{
${ }^{36}$ We conducted three additional exercises to test for the exogeneity of living next door to a PCL ticket buyer. First, within winning postcodes (where we know the location of all buyers) we examined the sample of nonbuyers and asked whether their tendency to live next door to a buyer was related to any of their observable characteristics (using a method similar to Appendix Table A2). Second, we conducted the same test in both winning and nonwinning codes using a survey-based indicator of whether one's neighbor purchased tickets that is available in both types of codes (described in the following paragraph). Third, we added this indicator as a control variable to some of our 'social effects' regressions, such as those reported in Table 8. None of these exercises indicated a significant or robust association between living next door to a lottery winner and other observed characteristics (including prelottery income).
} 
As noted, the other indicator of conspicuous consumption (i.e. consumption that is easily observable to its neighbors over an extended period) available to us is whether a household undertook any exterior home renovations during the six months since the lottery. As Table 3 indicated, this is a relatively rare event (occuring in 1.5 versus 3.0 percent of households in nonwinning versus winning codes respectively); the odds of detecting an effect of the lottery are thus relatively small. Nonetheless we replicated Table 9's analysis of car consumption for renovations. Statistically significant social effects were detected only for postcode level measures of neighbors' winnings; only these measures are reported in Table 12 to save space. In sum, Table 12 provides weak but suggestive evidence that, when a large number of households in a postcode win, all households (including nonwinners) are more likely to conduct exterior renovations to their home, and less likely to conduct interior renovations. While this reallocation of consumption is consistent with ‘competitive' consumption behavior, it is also consistent with other motivations. $^{37}$

As a final exercise, we added interaction terms to our main estimates of social effects to identify the types of neighborhoods in which estimated social effects are the strongest. To illustrate the results, we focus on two cases where our estimated social effects in Table 8 were strongest: the effects of living in a winning code on new car purchases, and the effects of a large number of winning households in the postcode on exterior home renovations. The results are reported in Tables 13 and 14. The first five rows of these tables measure neighborhood characteristics by whether the respondent's postcode is above or below the sample mean on a given characteristic, such as age or education. The sixth simply differentiates postcodes in the

\footnotetext{
${ }^{37}$ For example, suppose that households derive utility from living near attractively-maintained homes. A neighborhood-level PCL win might provide a focal point that helps solve this public-good problem, either by stimulating communication among households or by providing simultaneous income shocks to multiple creditconstrained households.
} 
Netherlands' 30 largest cities from all other postcodes. The remaining rows differentiate the social effect by the characteristics of the respondent's dwelling. Specifically, we define a household as living in a multi-unit building if it shares an $(x, y)$ location with at least one other household in its codegroup; this method also allows us to differentiate households in small (up to 4 units) versus larger multiunit buildings. Because none of the above neighborhood characteristics vary much within codegroups, all the specifications in Tables 13 and 14 omit the codegroup fixed effects. ${ }^{38}$ The Tables show both the main effect of winnings in the neighborhood, and its interaction with a selected neighborhood or dwelling characteristic. ${ }^{39}$

According to Table 13, social effects of a PCL win on new car purchases are strongest in postcodes with an above-average share of single-headed households, with few children, in large cities, and in large, multi-unit dwellings. In contrast, according to Table 14, social effects of a large number of winning households on exterior home renovations are strongest outside the large cities and in small multi-unit dwellings. The latter result is consistent with the notion that a local PCL win facilitates co-ordination of building improvements, at least in cases where the number of households sharing a building is not large.

In other regressions (not shown), we also explored interactions between social effects and indicators of the social and economic homogeneity of the postcode (essentially whether the within-postcode variance of the characteristics in Tables 13 and 14 was above the sample average). No consistent associations were found. We also focused on a household's two and four nearest neighbors and asked whether estimated social effects were stronger when the social

\footnotetext{
${ }^{38}$ They also omit the vector of household characteristics, $X$. Our objective here is to examine the effects of variation in overall neighborhood type (including the household itself), not the distinct effects of own versus neighborhood characteristics on social interactions. (We ask whether social interactions are greater when a household's $X \mathrm{~s}$ 'match' its neighbors' later in this section).

39 "Main" effects of each characteristic are also included as controls, but not reported.
} 
distance between a winning neighbor and oneself (measured for example by the difference in household income or education levels, or whether the households match each other by headship type or presence of children) was smaller. Likely because the share of neighboring households for whom such characteristics are available in our survey is small, no statistically significant differences were detected.

\section{Summary}

We have used the natural experiment associated with the Dutch postcode lottery (PCL) to study both the own and social effects of a temporary, unexpected income shock equal to about eight months of income on households' consumption behavior and self-reported happiness. For most aspects of household consumption, we are able to rule out large effects of such a shock on own consumption in the six months after it occurs. This fact, plus the fact that the main consumption effects we do detect involve durables, is consistent with a permanent income model in which households use durable expenditures as well as capital markets to smooth consumption (Browning and Crossley 2004). In addition, as predicted by simple models of transfers in kind, the vast majority of households who exogenously receive a large, in-kind transfer (a new BMW) converted that prize into other goods or savings, despite the transactions cost and/or tax penalty associated with doing so. The only own consumption effect that is hard to reconcile with a simple permanent income model is our estimated effect of a PCL win on eating out six months after the lottery: while the effect we detect is small, it is still considerably larger than one would expect from a simple life cycle model. Also consistent with the life cycle model, we find that nondurables expenditures are less sensitive to lottery winnings than to cross-sectional income differentials. 
We do detect social effects of lottery winnings, but only for two goods: car consumption and exterior home renovations, both of which are likely to be easily, and repeatedly, visible to a household's neighbors. While we observe a strong cross-sectional association between (nonlottery) income and self-reported happiness in our data, lottery winnings do not make households happier, nor do they make neighboring households less happy. Together, these results are consistent with a scenario in which (a) happiness is more linked to permanent than to short-term increases in income, and (b) at least in the short term, income comparisons with one's residential neighbors do not affect happiness.

What simple models of consumer behavior might explain the social effects estimated in our data? While it is tempting to interpret our estimates as reflective of a psychological need to (be seen to be?) "keeping up with the van den Bergs" ${ }^{\text {, }}$, we note that they could also be driven by other factors. For example, our results for home renovations are also consistent with a scenario where a simultaneous lottery win provides a focal point (and perhaps eases liquidity constraints) for voluntary contributions to the local public good of neighborhood (or even building) appearance. Social spillovers in car consumption in our data could be driven by informationsharing about cars and/or dealers (Grinblatt et al, 2004), or by something as simple as households passing money to immediate neighbors, who might be family members. Also, it is worth reemphasizing that our estimates do not distinguish 'imitative' consumption patterns (I buy a car because you buy one) from more general effects of neighbors' incomes on a household's consumption. Still, we find that households' consumption of visible, durable goods (and only such goods) are affected by exogenous shocks to their neighbors' incomes. We find these effects intriguing and deserving of further study using lottery-based or other research designs.

\footnotetext{
${ }^{40}$ Parallel to "Jones", van den Berg is the fourth most common surname in the Netherlands, according to Wikipedia. (De Jong is first).
} 
Finally, we note that, when taken together, our own and social effects results can -perhaps paradoxically-- be seen as 'good news' for both the life-cycle hypothesis (suitably modified to include durables' consumption-smoothing role) and for fiscal policies such as unexpected tax rebates designed to stimulate consumer spending: To the extent that the latter aim specifically at "big-ticket items" (mostly durables) -where consumer spending is most cyclically sensitive to begin with—our results suggest that unexpected income shocks (such as tax rebates) may not only have substantial 'own' effects on consumption, but significant social multiplier effects as well (Glaeser et al., 2003). These social multipliers are distinct from, and would presumably operate in addition to, the usual Keynesian multipliers that have been studied in this context. 


\section{References}

Agarwal, Sumit, Chunlin Liu, and Nicholas S. Souleles. 2007 "The Reaction of Consumer Spending and Debt to Tax Rebates-Evidence from Consumer Credit Data” Journal of Political Economy 115(6) (December): 986-1019.

Bagwell, L. S., and B. D. Bernheim (1996): "Veblen Effects in a Theory of Conspicuous Consumption," American Economic Review, 86(3), 349- 373.

Becker, G. S., and K. M. Murphy (2001): Social Economics; Market Behavior in a Social Environment. Belknap Print.

Browning, M. and T. Crossley. (2004) "Shocks, stocks and socks: smoothing consumption over a temporary income loss" Centre for Applied Microeconometrics, University of Copenhagen, working paper no. 2004-05 (March)

Duflo, E., M. Kremer, and J. Robinson (2004): "Understanding Technology Adoption: Fertilizer in Western Kenya - Preliminary Results from Field Experiments,” Unpublished manuscript, Massachusetts Institute of Technology.

Duflo, E., and E. Saez (2003): "The Role of Information and Social Interactions in Retirement Plan Decisions: Evidence from a Randomized Experiment," Quarterly Journal of Economics, 118(3), 815-842.

Easterlin, Richard A. "Does Economic Growth Improve the Human Lot? Some Empirical Evidence”. In Nations and Households in Economic Growth: Essays in Honor of Moses Abramowits, Paul A. David and Melvin Reder, eds. New York: Academic Press, 1974.

Gardner, Jonathan and Andrew J. Oswald (2007) "Money and mental wellbeing: A longitudinal study of medium-sized lottery wins" Journal of Health Economics 26 (2007) 49-60

Glaeser,Edward L., Bruce I. Sacerdote and Jose A. Scheinkman. (2003) "The Social Multiplier”. Journal of the European Economic Association1(2-3) (April-May): 345-53

Grinblatt, Mark, Matti Keloharju and Seppo Ikaheimo. (2004) “Interpersonal Effects in Consumption: Evidence from the Automobile Purchases of Neighbors" NBER working paper no. 10226

Imbens, G., D. Rubin, and B. Sacerdote, "Estimating the Effect of Unearned Income on Labor Earnings, Savings and Consumption: Evidence from a Survey of Lottery Players" American Economic Review 91(4)(September 2001): 778-794.

Kahneman, Daniel, Alan Krueger, David Schkade, Norbert Schwarz, and Arthur Stone. (2006) "Would You Be Happier If You Were Richer? A Focusing Illusion": Princeton University, Department of Economics, Center for Economic Policy Studies, Working Paper. 
Katz, L. F., J. R. Kling, and J. B. Liebman (2001): "Moving To Opportunity in Boston: Early Results of a Randomized Mobility Experiment,” Quarterly Journal of Economics, 116, 607-654.

Kling, J. R., J. Ludwig, and L. F. Katz (2005): "Neighborhood Effects on Crime for Female and Male Youth: Evidence from a Randomized Housing Voucher Experiment,” Quarterly Journal of Economics, pp. 87-130.

Leibenstein, H. (1950): "Bandwagon, Snob, and Veblen Effects in the Theory of Consumer's Demand," Quarterly Journal of Economics, 64, 183-207.

Ludwig, J., G. J. Duncan, and P. Hirschfield (2001): “Urban Poverty and Juvenile Crime: Evidence from a Randomized Housing-Mobility Experiment," Quarterly Journal of Economics, CXVI, 655-679.

Luttmer, Erzo. (2005) “Neighbors as Negatives: Relative Earnings and Well-Being” Quarterly Journal of Economics, 120(3) (August): 963-1002.

Manski, Charles, (1993). "Identification of Endogenous Social Effects: The Reflection Problem," Review of Economic Studies, 60(3), 531-42.

Miguel, E. and Kremer, M. (2004). Worms: identifying impacts on education and health in the presence of treatment externalities. Econometrica 72(1): 159-217.

Moffitt, R. A. (1984). The effects of grants-in-aid on state and local expenditures: The case of AFDC. Journal of Public Economics, 23, 279-305.

Moffitt, R. A. (1989). Estimating the value of an in-kind transfer: The case of food stamps. Econometrica, 57(2), 385-409.

Moffitt, R. A. (2001): "Policy Interventions, Low-Level Equilibria, and Social Interactions," in Social Dynamics, ed. by S. N. Durlauf, and H. P. Young, pp. 45-82. MIT Press.

Pollak, R. A. (1976): “Interdependent Preferences,” American Economic Review, 66(3), 309321.

Sacerdote, Bruce, (2001) "Peer Effects with Random Assignment: Results for Dartmouth Roommates,” Quarterly Journal of Economics, 116(2), 681-704.

Stevenson, Betsey and Justin Wolfers (2008). "Economic Growth and Subjective Well-Being: Reassessing the Easterlin Paradox" unpublished manuscript, Wharton, University of Pennsylvania, April 16.

Zeelenberg, M. and Pieters, F.G.M. (2004). "Consequences of regret aversion in real life: The case of the Dutch postcode lottery". Organization Behavior and Human Decision Processes, 93, 155-168 
Table 1: Descriptive Statistics, Pre-Lottery Characteristics

\begin{tabular}{|c|c|c|}
\hline \multirow{2}{*}{ Permanent or pre-Lottery Characteristic: } & \multicolumn{2}{|c|}{ Live in a winning postcode? } \\
\hline & No & Yes \\
\hline Number of persons in household ${ }^{1}$ & 2.28 & 2.36 \\
\hline Two-headed Household? $^{1}$ & .628 & .683 \\
\hline Secondary Education ${ }^{2}$ & .915 & .925 \\
\hline Higher Vocational Training or University? ${ }^{2}$ & .338 & .308 \\
\hline $\mathrm{Age}^{3}$ & 49.90 & 50.64 \\
\hline Number of children in household & .513 & .562 \\
\hline \multicolumn{3}{|l|}{ For single-headed households: } \\
\hline Head works? & .434 & .477 \\
\hline Head's hours $^{4}$ & 14.30 & 16.65 \\
\hline \multicolumn{3}{|l|}{ For two-headed households: } \\
\hline Husband works? & .665 & .641 \\
\hline Husbands' hours ${ }^{4}$ & 25.23 & 24.19 \\
\hline Wife works? & .572 & .555 \\
\hline Wife's hours ${ }^{4}$ & 15.99 & 15.45 \\
\hline \multicolumn{3}{|l|}{ Monthly Expenditures: (euro, one year before survey date) } \\
\hline Food at home & 435.24 & 428.70 \\
\hline Food away from home & 96.21 & 96.23 \\
\hline Transportation & 177.87 & 188.84 \\
\hline Other monthly & 239.82 & 261.75 \\
\hline Total monthly & 947.60 & 957.98 \\
\hline \multicolumn{3}{|l|}{ Occasional Expenditures: } \\
\hline Exterior Home renovations before lottery (any?) ${ }^{5}$ & .052 & .049 \\
\hline Other Home renovations before lottery (any?) ${ }^{5,6}$ & .171 & .150 \\
\hline Vacation expenditures before lottery (euro) ${ }^{5}$ & 339 & 471 \\
\hline Durables expenditures before lottery (euro) ${ }^{5}$ & 1616 & 1661 \\
\hline Total Annual Household Income (euro, post tax, pre lottery) & 23358 & 24045 \\
\hline Happiness $^{7}$ & 6.73 & 6.82 \\
\hline Sample size $^{8}$ & 1179 & 701 \\
\hline
\end{tabular}

Notes: Statistically significant differences at $5 \%$ in bold, at $10 \%$ in italics.

1. refers to one year before the survey date.

2. For single-headed households, indicates whether the head has at least the level of education indicated. For twoheaded households, indicates whether at least one head has this level of education.

3. For single-headed households, age in years. For two-headed households, a simple average of the husband's and wife's ages.

4. Usual weekly hours one year before the survey date. Equals zero for non-workers.

5. Refers to the 18 month period preceding the lottery date.

6. Includes interior renovations and those whose type could not be determined.

7. Self assessed on a scale from 1 to 10 (refers to one year before the survey date)

8. Gives the number of observations in winning and nonwinning codes. Sample sizes vary across rows of the table due to missing values and sample restrictions. 
Table 2: Descriptive Statistics, Lottery Characteristics

\begin{tabular}{|c|c|c|}
\hline & \multicolumn{2}{|c|}{ Live in a winning postcode? } \\
\hline & No & Yes \\
\hline \multicolumn{3}{|l|}{ Awareness of Lottery: } \\
\hline Remember PCL Street Prize? & .653 & .874 \\
\hline Recall number of winning households? & 221 & .533 \\
\hline Recall winners’ house numbers? & .053 & .248 \\
\hline \multicolumn{3}{|c|}{ Lottery Participation and Winnings (unconditional): } \\
\hline Held a PCL ticket? & .255 & 318 \\
\hline Number of tickets held & .455 & .564 \\
\hline Amount of Cash Won (euro) & $\mathbf{0}$ & 5915 \\
\hline Won BMW? & $\mathbf{0}$ & .037 \\
\hline Total Winnings (incl. value of BMW) & $\mathbf{0}$ & 6843 \\
\hline \multicolumn{3}{|c|}{ Lottery Tickets and Winnings (conditional on participation): } \\
\hline Number of tickets held & 1.853 & 1.783 \\
\hline Amount of Cash Won (euro) & $\mathbf{0}$ & 18596 \\
\hline Won BMW? & $\mathbf{0}$ & .112 \\
\hline Total Winnings (incl. value of BMW) & $\mathbf{0}$ & 21399 \\
\hline \multicolumn{3}{|l|}{ Indicators of Neighbors' Winnings: } \\
\hline Had an immediate neighbor who won? & $\mathbf{0}$ & .524 \\
\hline $\begin{array}{l}\text { Number of immediate neighbors who won } \\
(0,1 \text { or } 2)\end{array}$ & $\mathbf{0}$ & .635 \\
\hline $\begin{array}{l}\text { Total amount won by immediate neighbors } \\
\text { (incl. value of BMW) }\end{array}$ & $\mathbf{0}$ & 13392 \\
\hline \multicolumn{3}{|l|}{ Number of winning households: } \\
\hline In same building & 428 & 2.463 \\
\hline Within 25 meters & .497 & 3.010 \\
\hline Within 100 meters & 4.079 & 7.027 \\
\hline In your postcode & $\mathbf{0}$ & 8.491 \\
\hline \multicolumn{3}{|l|}{ Total Amount Won: } \\
\hline In same building & 11297 & 63252 \\
\hline Within 25 meters & 12947 & 77328 \\
\hline Within 100 meters & 101831 & 178223 \\
\hline In your postcode & $\mathbf{0}$ & 217980 \\
\hline \multicolumn{3}{|l|}{ Proximity to BMWs: } \\
\hline Immediate neighbor won a BMW? & $\mathbf{0}$ & .081 \\
\hline \multicolumn{3}{|l|}{ Number of BMWs won: } \\
\hline In same building & .067 & .302 \\
\hline Within 25 meters & .078 & .371 \\
\hline Within 100 meters & .471 & .699 \\
\hline In your postcode & $\mathbf{0}$ & .814 \\
\hline
\end{tabular}

Notes: Statistically significant differences at $5 \%$ in bold.

Indicators of own winnings and tickets bought are taken from survey data, and cross-checked against PCL data for winners. BMW-winner indicator is taken from PCL data only. Indicators of neighbors' and post-code level winnings are taken from PCL data. 
Table 3: Descriptive Statistics, Outcome Variables

\begin{tabular}{|c|c|c|}
\hline & \multicolumn{2}{|c|}{ Live in a winning postcode? } \\
\hline & No & Yes \\
\hline \multicolumn{3}{|l|}{$\begin{array}{l}\text { Monthly Expenditures: } \\
\text { (euro, at the survey date) }\end{array}$} \\
\hline Food at home & 469.71 & 464.45 \\
\hline Food away from home & 94.18 & 101.59 \\
\hline Transportation & 191.71 & 216.87 \\
\hline Other monthly & 255.11 & 298.07 \\
\hline Total monthly $^{1}$ & 1000.56 & 1080.51 \\
\hline \multicolumn{3}{|l|}{ Occasional Expenditures: } \\
\hline Exterior Home renovations before lottery (any?) & .015 & .030 \\
\hline Other Home renovations before lottery (any?) & .075 & .067 \\
\hline${\text { Vacation expenditures since lottery (euro) }{ }^{2}}^{2}$ & 260.25 & 274.54 \\
\hline Durables expenditures since lottery (euro) ${ }^{2}$ & 768.21 & 889.18 \\
\hline $\begin{array}{l}\text { Total Annual Household Income (euro, at } \\
\text { survey date) }\end{array}$ & 24185 & 25546 \\
\hline \multicolumn{3}{|l|}{ Car Variables: } \\
\hline New Car since Lottery Date? ${ }^{3}$ & .111 & .157 \\
\hline Own a BMW at the Survey Date? & .0204 & .0157 \\
\hline Number of Cars (up to 2) & .999 & 1.086 \\
\hline Age of Main Car (years) & 7.08 & 6.31 \\
\hline Total Car Efficiency Units ${ }^{4}$ & .380 & .455 \\
\hline \multicolumn{3}{|l|}{ Car Variables, non-BMW winners only: } \\
\hline New Car since Lottery Date? ${ }^{3}$ & .111 & .148 \\
\hline Own a BMW at the Survey Date? & .0204 & .0104 \\
\hline Number of Cars (up to 2) & .999 & 1.079 \\
\hline Age of Main Car (years) & 7.08 & 6.392 \\
\hline Total Car Efficiency Units ${ }^{4}$ & .380 & .447 \\
\hline \multicolumn{3}{|l|}{ Other Outcomes: } \\
\hline Happiness $^{5}$ & 6.88 & 6.93 \\
\hline PCL participant at Survey Date? & .333 & .361 \\
\hline Donate Survey Fee to Charity? & .424 & .466 \\
\hline
\end{tabular}

Notes: Statistically significant differences at $5 \%$ in bold, at $10 \%$ in italics.

1. Sum of food at home, food away from home, transportation plus other expenditures.

2. Refers to the 6 month period between the lottery and survey dates.

3. Equals one if the household acquired any of the autos it currently owns after the lottery date.

4. A car that is less than one year old counts as one unit. All other cars are depreciated at 15 percent per year.

5. Self assessed on a scale from 1 to 10 (refers to the survey date) 
Table 4: BMW Ownership Six Months After the Lottery

\begin{tabular}{|l|c|c|c|}
\hline & $\begin{array}{c}\text { Number with } \\
\text { a BMW }\end{array}$ & $\begin{array}{c}\text { Share with a } \\
\text { BMW }\end{array}$ & $\begin{array}{c}\text { Number } \\
\text { Of Observations }\end{array}$ \\
\hline $\begin{array}{l}\text { Nonwinners- } \\
\text { Nonwinning codes }\end{array}$ & 24 & 2.04 & 1179 \\
\hline $\begin{array}{l}\text { Nonwinners- } \\
\text { Winning codes }\end{array}$ & 4 & 0.79 & 506 \\
\hline $\begin{array}{c}\text { All Nonwinners } \\
\text { combined }\end{array}$ & $\mathbf{2 8}$ & $\mathbf{1 . 6 6}$ & $\mathbf{1 6 8 5}$ \\
\hline $\begin{array}{c}\text { Cash winner } \\
\text { BMW Winner }\end{array}$ & 3 & 1.78 & 169 \\
\hline \multicolumn{1}{|c|}{ All Respondents } & $\mathbf{3 5}$ & 15.38 & 26 \\
\hline
\end{tabular}


Table 5: Simple Estimates of Own and Social Effects of Lottery Winnings on Consumption

\begin{tabular}{|c|c|c|c|c|}
\hline \multirow{3}{*}{ Consumption Measure: } & \multicolumn{4}{|c|}{ Effect of living in a winning code on consumption } \\
\hline & \multicolumn{2}{|c|}{ For PCL ticket holders } & \multicolumn{2}{|c|}{ For non-ticket holders } \\
\hline & (1) & (2) & (3) & (4) \\
\hline \multicolumn{5}{|c|}{ CAR OWNERSHIP, including BMW winners: } \\
\hline $\begin{array}{l}\text { Acquired new car since lottery } \\
\text { date? }\end{array}$ & $\begin{array}{l}.0395 \\
(.0294)\end{array}$ & $\begin{array}{l}.0364 \\
(.0346)\end{array}$ & $\begin{array}{l}.0489 \\
(.0194)\end{array}$ & $\begin{array}{l}.0439 \\
(.0173)\end{array}$ \\
\hline Own a BMW at the survey date? & $\begin{array}{l}-.0052 \\
(.0171)\end{array}$ & $\begin{array}{l}-.0273 \\
(.0158)\end{array}$ & $\begin{array}{l}-.0064 \\
(.0062)\end{array}$ & $\begin{array}{l}-.0104 \\
(.0044)\end{array}$ \\
\hline $\begin{array}{l}\text { Number of cars at survey date (up } \\
\text { to two) }\end{array}$ & $\begin{array}{l}.0126 \\
(.0601)\end{array}$ & $\begin{array}{l}-.0337 \\
(.0607)\end{array}$ & $\begin{array}{l}.0958 \\
(.0511)\end{array}$ & $\begin{array}{l}.0089 \\
(.0351)\end{array}$ \\
\hline Age of main car (years) & $\begin{array}{l}-1.120 \\
(.414)\end{array}$ & $\begin{array}{l}-1.436 \\
(.3982)\end{array}$ & $\begin{array}{l}-.3661 \\
(.3223)\end{array}$ & $\begin{array}{l}-.1842 \\
(.2697)\end{array}$ \\
\hline Car efficiency units & $\begin{array}{l}.0872 \\
(.0427)\end{array}$ & $\begin{array}{l}.0655 \\
(.0350)\end{array}$ & $\begin{array}{l}.0592 \\
(.0293)\end{array}$ & $\begin{array}{l}.0165 \\
.0194\end{array}$ \\
\hline \multicolumn{5}{|c|}{ CAR OWNERSHIP, excluding BMW winners from the sample: } \\
\hline $\begin{array}{l}\text { Acquired new car since lottery } \\
\text { date? }\end{array}$ & $\begin{array}{l}.0083 \\
(.0297)\end{array}$ & $\begin{array}{c}.0174 \\
(.0360)\end{array}$ & $\begin{array}{l}.0489 \\
(.0194)\end{array}$ & $\begin{array}{l}.0439 \\
(.0173)\end{array}$ \\
\hline Own a BMW at the survey date? & $\begin{array}{l}-.0214 \\
(.0158)\end{array}$ & $\begin{array}{l}-.0398 \\
(.0141)\end{array}$ & $\begin{array}{l}-.0064 \\
(.0062)\end{array}$ & $\begin{array}{l}-.0104 \\
(.0044)\end{array}$ \\
\hline $\begin{array}{l}\text { Number of cars at survey date (up } \\
\text { to two) }\end{array}$ & $\begin{array}{l}.0095 \\
.0629\end{array}$ & $\begin{array}{l}-.0300 \\
(.0637)\end{array}$ & $\begin{array}{l}.0958 \\
(.0511)\end{array}$ & $\begin{array}{l}.0089 \\
(.0351)\end{array}$ \\
\hline Age of main car (years) & $\begin{array}{l}-1.1142 \\
(.4203)\end{array}$ & $\begin{array}{l}-1.3703 \\
(.4232)\end{array}$ & $\begin{array}{l}-.3661 \\
(.3223)\end{array}$ & $\begin{array}{l}-.1842 \\
(.2697)\end{array}$ \\
\hline Car efficiency units & $\begin{array}{l}.0776 \\
(.0444)\end{array}$ & $\begin{array}{c}.0592 \\
(.0369)\end{array}$ & $\begin{array}{c}.0592 \\
(.0293)\end{array}$ & $\begin{array}{l}.0165 \\
.0194 \\
\end{array}$ \\
\hline \multicolumn{5}{|l|}{ MONTHLY EXPENDITURES: } \\
\hline Food at home: (euros) & $\begin{array}{c}29.65 \\
(32.73) \\
\end{array}$ & $\begin{array}{c}24.75 \\
(39.18) \\
\end{array}$ & $\begin{array}{l}-20.90 \\
(45.17)\end{array}$ & $\begin{array}{l}-53.90 \\
(35.87) \\
\end{array}$ \\
\hline (square root of euros) & $\begin{array}{l}.6833 \\
(.6147)\end{array}$ & $\begin{array}{l}.8031 \\
(.6586)\end{array}$ & $\begin{array}{l}-.0747 \\
(.5857)\end{array}$ & $\begin{array}{l}-.5365 \\
(.4398)\end{array}$ \\
\hline (change, euros) & $\begin{array}{l}10.96 \\
(7.56)\end{array}$ & $\begin{array}{c}21.43 \\
9.89\end{array}$ & $\begin{array}{l}12.75 \\
(7.40)\end{array}$ & $\begin{array}{l}14.87 \\
(6.18)\end{array}$ \\
\hline (change in square root) $^{1}$ & $\begin{array}{l}.5809 \\
(.5289)\end{array}$ & $\begin{array}{l}1.2702 \\
(.6311)\end{array}$ & $\begin{array}{c}.4722 \\
(.4168)\end{array}$ & $\begin{array}{l}.6605 \\
(.3829)\end{array}$ \\
\hline Food away from home: (euros) & $\begin{array}{c}40.87 \\
(14.58)\end{array}$ & $\begin{array}{c}27.42 \\
(13.84)\end{array}$ & $\begin{array}{c}-6.91 \\
(13.66)\end{array}$ & $\begin{array}{l}-14.06 \\
(13.69)\end{array}$ \\
\hline (square root of euros) & $\begin{array}{l}1.4813 \\
(.6216)\end{array}$ & $\begin{array}{l}1.0756 \\
(.6226)\end{array}$ & $\begin{array}{l}-.1402 \\
(.4238)\end{array}$ & $\begin{array}{l}-.2491 \\
(.3406)\end{array}$ \\
\hline (change, euros) & $\begin{array}{c}9.41 \\
(7.58) \\
\end{array}$ & $\begin{array}{c}-3.73 \\
(11.98)\end{array}$ & $\begin{array}{c}8.09 \\
(5.78)\end{array}$ & $\begin{array}{c}8.96 \\
(5.00)\end{array}$ \\
\hline (change in square root) $^{1}$ & $\begin{array}{l}1.0143 \\
(.4742)\end{array}$ & $\begin{array}{l}.4565 \\
(6236)\end{array}$ & $\begin{array}{l}.2767 \\
(.3323)\end{array}$ & $\begin{array}{l}.3413 \\
(.3154)\end{array}$ \\
\hline $\begin{array}{l}\text { Transportation expenditures: } \\
\text { (euros) }\end{array}$ & $\begin{array}{c}23.99 \\
(28.20)\end{array}$ & $\begin{array}{l}-15.60 \\
(26.82)\end{array}$ & $\begin{array}{c}25.92 \\
(34.11)\end{array}$ & $\begin{array}{c}21.62 \\
(24.45)\end{array}$ \\
\hline (square root of euros) & $\begin{array}{c}.4502 \\
.(6865)\end{array}$ & $\begin{array}{l}-.5808 \\
(.7368)\end{array}$ & $\begin{array}{c}.7006 \\
(.5713)\end{array}$ & $\begin{array}{c}.3031 \\
(.4317)\end{array}$ \\
\hline (change, euros) & $\begin{array}{l}-1.23 \\
(7.83)\end{array}$ & $\begin{array}{l}-1.40 \\
(9.70)\end{array}$ & $\begin{array}{l}-1.49 \\
(8.97)\end{array}$ & $\begin{array}{c}3.61 \\
(5.60)\end{array}$ \\
\hline (change in square root) $^{1}$ & $\begin{array}{l}-.1376 \\
(.5101)\end{array}$ & $\begin{array}{c}-.0514 \\
(.6735)\end{array}$ & $\begin{array}{c}.0764 \\
(.3721)\end{array}$ & $\begin{array}{c}.2127 \\
(.3012)\end{array}$ \\
\hline
\end{tabular}




\begin{tabular}{|c|c|c|c|c|}
\hline Other monthly: (euros) & $\begin{array}{c}81.21 \\
(45.06)\end{array}$ & $\begin{array}{c}82.27 \\
(52.48) \\
\end{array}$ & $\begin{array}{c}25.80 \\
(35.80)\end{array}$ & $\begin{array}{c}11.60 \\
(31.29)\end{array}$ \\
\hline (square root of euros) & $\begin{array}{l}1.2566 \\
(.7623)\end{array}$ & $\begin{array}{l}1.1626 \\
(.8532)\end{array}$ & $\begin{array}{c}.4070 \\
(.5373)\end{array}$ & $\begin{array}{l}.1064 \\
(.4492)\end{array}$ \\
\hline (change, euros) & $\begin{array}{l}15.51 \\
(9.71) \\
\end{array}$ & $\begin{array}{l}14.17 \\
(8.97) \\
\end{array}$ & $\begin{array}{c}8.84 \\
(6.64) \\
\end{array}$ & $\begin{array}{c}6.07 \\
(6.59) \\
\end{array}$ \\
\hline (change in square root) $^{1}$ & $\begin{array}{c}.9552 \\
(.5390) \\
\end{array}$ & $\begin{array}{c}.9734 \\
(.6209) \\
\end{array}$ & $\begin{array}{c}.5415 \\
(.3567) \\
\end{array}$ & $\begin{array}{r}.3923 \\
(.3748) \\
\end{array}$ \\
\hline Total monthly (euros): & $\begin{array}{l}185.77 \\
(87.91)\end{array}$ & $\begin{array}{l}130.36 \\
(86.87) \\
\end{array}$ & $\begin{array}{c}33.36 \\
(95.38) \\
\end{array}$ & $\begin{array}{c}-20.02 \\
(76.12)\end{array}$ \\
\hline (square root of euros) & \begin{tabular}{|l|}
2.1593 \\
1.0128 \\
\end{tabular} & $\begin{array}{l}1.6294 \\
(.9822) \\
\end{array}$ & $\begin{array}{c}.4656 \\
(.8567) \\
\end{array}$ & $\begin{array}{l}-.1616 \\
(.6380) \\
\end{array}$ \\
\hline (change, euros) & $\begin{array}{c}30.47 \\
(18.76)\end{array}$ & $\begin{array}{c}25.08 \\
(24.37)\end{array}$ & $\begin{array}{c}20.01 \\
(17.97)\end{array}$ & $\begin{array}{c}31.09 \\
(16.10)\end{array}$ \\
\hline (change in square root) $^{1}$ & $\begin{array}{l}1.4423 \\
(.8464)\end{array}$ & $\begin{array}{c}1.2356 \\
(1.0646)\end{array}$ & $\begin{array}{c}.5993 \\
(.7047)\end{array}$ & $\begin{array}{c}.9730 \\
(.6687)\end{array}$ \\
\hline \multicolumn{5}{|l|}{ OCCASIONAL EXPENDITURES: } \\
\hline Home renovations: (any exterior?) & $\begin{array}{c}.0349 \\
(.0142)\end{array}$ & $\begin{array}{l}.0404 \\
.0166\end{array}$ & $\begin{array}{c}.0059 \\
(.0106)\end{array}$ & $\begin{array}{c}.0055 \\
(.0083) \\
\end{array}$ \\
\hline (any other?) & $\begin{array}{l}-.0113 \\
(.0234)\end{array}$ & $\begin{array}{l}-.0216 \\
(.0282)\end{array}$ & $\begin{array}{l}-.0069 \\
(.0150)\end{array}$ & $\begin{array}{l}-.0190 \\
(.0131)\end{array}$ \\
\hline Vacation expenditures: (any?) & $\begin{array}{c}.0525 \\
(.0271) \\
\end{array}$ & $\begin{array}{l}.0390 \\
.0262 \\
\end{array}$ & $\begin{array}{l}-.0018 \\
(.0149) \\
\end{array}$ & $\begin{array}{l}-.0038 \\
(.0142) \\
\end{array}$ \\
\hline (euros) & $\begin{array}{c}33.29 \\
(275.95) \\
\end{array}$ & $\begin{array}{l}-340.47 \\
(533.48) \\
\end{array}$ & $\begin{array}{c}-18.01 \\
(53.40)\end{array}$ & $\begin{array}{c}-40.62 \\
(50.62) \\
\end{array}$ \\
\hline (square root of euros) & $\begin{array}{c}2.8898 \\
(1.8353) \\
\end{array}$ & $\begin{array}{c}1.1757 \\
(2.4830) \\
\end{array}$ & $\begin{array}{r}-.1375 \\
(.7625) \\
\end{array}$ & $\begin{array}{l}-.3814 \\
(.7431) \\
\end{array}$ \\
\hline Durable expenditures: (any?) & $\begin{array}{c}.0563 \\
(.0410) \\
\end{array}$ & $\begin{array}{c}.0201 \\
(.0461)\end{array}$ & $\begin{array}{c}-.0211 \\
(.0222)\end{array}$ & $\begin{array}{l}-.0321 \\
(.0192)\end{array}$ \\
\hline (euros) & $\begin{array}{c}532.91 \\
(272.79) \\
\end{array}$ & $\begin{array}{c}707.29 \\
(313.45) \\
\end{array}$ & $\begin{array}{c}-57.69 \\
(222.70) \\
\end{array}$ & $\begin{array}{c}-36.46 \\
(182.79) \\
\end{array}$ \\
\hline (square root) & $\begin{array}{c}5.8324 \\
(2.6258) \\
\end{array}$ & $\begin{array}{c}5.4824 \\
(3.0535) \\
\end{array}$ & $\begin{array}{c}-.7171 \\
(1.4559) \\
\end{array}$ & $\begin{array}{r}-1.2065 \\
(1.2973) \\
\end{array}$ \\
\hline \multicolumn{5}{|l|}{ OTHER OUTCOMES: } \\
\hline Happiness (level) & $\begin{array}{c}.0363 \\
(.1468)\end{array}$ & $\begin{array}{c}.0165 \\
(.1372)\end{array}$ & $\begin{array}{c}.0447 \\
(.1139)\end{array}$ & $\begin{array}{l}-.0967 \\
(.0890)\end{array}$ \\
\hline (change) & $\begin{array}{c}.0011 \\
(.1213)\end{array}$ & $\begin{array}{l}-.0819 \\
(.1370)\end{array}$ & $\begin{array}{l}-.0546 \\
(.0759)\end{array}$ & $\begin{array}{l}-.0027 \\
(.0754)\end{array}$ \\
\hline $\begin{array}{l}\text { Participate in PCL at Survey } \\
\text { Date? }\end{array}$ & $\begin{array}{c}.0091 \\
(.0245)\end{array}$ & $\begin{array}{l}-.0188 \\
(.0259)\end{array}$ & $\begin{array}{l}-.0368 \\
(.0189) \\
\end{array}$ & $\begin{array}{l}-.0437 \\
(.0166) \\
\end{array}$ \\
\hline Donate Survey Fee to Charity? & $\begin{array}{l}.0828 \\
(.0493)\end{array}$ & $\begin{array}{l}.1247 \\
(.0499)\end{array}$ & $\begin{array}{c}.0213 \\
(.0285)\end{array}$ & $\begin{array}{c}.0364 \\
(.0265) \\
\end{array}$ \\
\hline $\mathbf{N}$ (levels) & 506 & 506 & 1293 & 1293 \\
\hline $\mathbf{N}$ (changes) & 430 & 430 & 1028 & 1028 \\
\hline
\end{tabular}

Notes: columns 1 and 3 simply regress the consumption measure on a dummy for living in a winning code. Columns 2 and 4 add a full set of codegroup fixed effects to this regression. Sample sizes (N) are for food at home; sample sizes vary slightly for other outcomes due to missing data.

See previous tables for variable definitions. All specifications regress an indicator of consumption on a dummy for living in a winning code. Bold indicates significant at 5\%; italic indicates significant at $10 \%$. Standard errors clustered by postcode.

1. If the change in consumption $(x)$ is negative, this equals minus the square root of minus $x$. 
Table 6: Own Effects of Total Amount won in the Lottery

\begin{tabular}{|c|c|c|c|c|c|c|}
\hline \multirow[t]{2}{*}{ Outcome } & \multicolumn{2}{|c|}{ Basic Specification } & \multicolumn{2}{|c|}{$\begin{array}{c}\text { With Codegroup } \\
\text { effects }\end{array}$} & \multicolumn{2}{|c|}{$\begin{array}{c}\text { Codegroup effects } \\
\text { and Xs }\end{array}$} \\
\hline & coefficient & std. error & coefficient & std. error & coefficient & std. error \\
\hline & (1) & (2) & (3) & (4) & (5) & (6) \\
\hline \multicolumn{7}{|c|}{ CAR OWNERSHIP (excluding BMW winners from the sample): } \\
\hline Acquired new car since lottery date? & -.001 & .014 & .007 & .016 & .013 & .016 \\
\hline Own a BMW at survey date? & .005 & .011 & .001 & .008 & -.000 & .008 \\
\hline Number of cars at survey (up to two) & .015 & .028 & .008 & .027 & .013 & .024 \\
\hline Age of main car (years) & -.422 & .184 & -.468 & .197 & -.367 & .200 \\
\hline Car efficiency units & .042 & .020 & .042 & .021 & .035 & .021 \\
\hline \multicolumn{7}{|l|}{ MONTHLY EXPENDITURES: } \\
\hline Food at home: (euros) & 3.89 & 11.21 & 3.49 & 15.88 & 4.66 & 14.70 \\
\hline (square root of euros) & .021 & .191 & .044 & .225 & .031 & .203 \\
\hline (change, euros) & -2.02 & 2.44 & -1.88 & 2.37 & -1.98 & 2.48 \\
\hline (change in square root) $^{1}$ & -.135 & .182 & -.170 & .186 & -.166 & .190 \\
\hline Food away from home: (euros) & 18.98 & 7.87 & 19.24 & 7.97 & 17.49 & 7.77 \\
\hline (square root of euros) & .623 & .247 & .683 & .261 & .644 & .244 \\
\hline (change, euros) & 5.33 & 3.81 & 4.75 & 4.19 & 5.00 & 4.01 \\
\hline (change in square root) $^{1}$ & .384 & .193 & .348 & .220 & .365 & .209 \\
\hline Transportation expenditures: (euros) & 2.95 & 9.72 & 3.69 & 10.58 & 3.56 & 11.18 \\
\hline (square root of euros) & .056 & .217 & .064 & .239 & .010 & .238 \\
\hline (change, euros) & -0.67 & 2.27 & -0.01 & 2.84 & 1.02 & 3.41 \\
\hline (change in square root) $^{1}$ & -.069 & .146 & -.066 & .157 & -.053 & .170 \\
\hline Other monthly: (euros) & 11.13 & 15.13 & 14.48 & 15.37 & 10.64 & 15.42 \\
\hline (square root of euros) & .137 & .249 & .190 & .271 & .110 & .260 \\
\hline (change, euros) & 0.05 & 2.42 & -0.81 & 2.87 & -.61 & 3.03 \\
\hline (change in square root) $^{1}$ & -.076 & .158 & -.145 & .188 & -.119 & .192 \\
\hline Total monthly (euros): & 36.10 & 34.26 & 36.59 & 36.50 & 36.11 & 35.23 \\
\hline (square root of euros) & .348 & .368 & .395 & .388 & .350 & .355 \\
\hline (change, euros) & 1.51 & 6.85 & -0.11 & 7.72 & 0.39 & 8.01 \\
\hline (change in square root) ${ }^{1}$ & .124 & .312 & -.093 & .375 & -.055 & .357 \\
\hline \multicolumn{7}{|l|}{ OCCASIONAL EXPENDITURES: } \\
\hline Home renovations: (any exterior?) & .002 & .003 & .004 & .003 & .004 & .003 \\
\hline (any other?) & .014 & .009 & .008 & .009 & .008 & .008 \\
\hline Vacation expenditures: (any?) & .010 & .007 & .007 & .008 & .007 & .008 \\
\hline (euros) & 42.82 & 35.27 & 6.12 & 53.30 & -0.02 & 58.29 \\
\hline (square root of euros) & .690 & .425 & .437 & .481 & .387 & .506 \\
\hline Durable expenditures: (any?) & .029 & .012 & .027 & .012 & .029 & .012 \\
\hline (euros) & 288.33 & 113.72 & 318.13 & 122.75 & 294.09 & 126.38 \\
\hline (square root) & 2.868 & 1.023 & 2.939 & 1.041 & 2.875 & 1.055 \\
\hline \multicolumn{7}{|l|}{ OTHER OUTCOMES: } \\
\hline Happiness (level) & -.014 & 055 & .008 & .050 & .007 & .054 \\
\hline (change) & -.010 & .029 & -.010 & .037 & .002 & .036 \\
\hline Participate in PCL at Survey Date? & .020 & .008 & .017 & .009 & .016 & .009 \\
\hline Donate Survey Fee to Charity? & -.004 & .013 & -.010 & .013 & -.011 & .013 \\
\hline
\end{tabular}

Notes: Total winnings are measured in euros/10000 and equal zero for nonwinners. Monetary value of BMW (valued at $€ 25,000$ ) is included in winnings. See previous tables for definitions of other variables. All specifications include a fixed effect for lottery participation, a quadratic in the number of tickets purchased, and an dummy for residence in a winning postcode. Covariates (Xs) in columns 5 and 6 are own household income 6 months before the lottery data, presence of a partner, number of children and its square, age and its square, and education controls. Bold indicates significant at 5\%; italic at $10 \%$. Standard errors clustered on postcodes.

1. If the change in consumption $(x)$ is negative, this equals minus the square root of minus $x$. 
Table 7: Comparing own Lottery Effects to Cross-sectional Engel Curves

\begin{tabular}{|c|c|c|c|c|}
\hline \multirow{3}{*}{ Outcome } & \multicolumn{4}{|c|}{ Income Component } \\
\hline & \multicolumn{2}{|c|}{$\begin{array}{c}\text { Household } \\
\text { Nonlottery Income }\end{array}$} & \multicolumn{2}{|c|}{ Lottery Winnings } \\
\hline & $\begin{array}{c}\text { Coeffi- } \\
\text { cient }\end{array}$ & $\begin{array}{l}\text { Std. } \\
\text { error }\end{array}$ & $\begin{array}{c}\text { Coeffi- } \\
\text { cient }\end{array}$ & $\begin{array}{c}\text { Std. } \\
\text { Error }\end{array}$ \\
\hline & (1) & (2) & (3) & (4) \\
\hline \multicolumn{5}{|l|}{ CAR OWNERSHIP $^{1}$} \\
\hline Acquired new car since lottery date? & .003 & .007 & .013 & .016 \\
\hline Number of cars at survey date (up to two) & .033 & .008 & .013 & .024 \\
\hline Age of main car (years) & -.114 & .078 & -.367 & .200 \\
\hline Car efficiency units & .024 & .006 & .035 & .021 \\
\hline \multicolumn{5}{|l|}{ MONTHLY EXPENDITURES: } \\
\hline Food at home (euros) & 9.44 & 11.17 & 4.66 & 14.70 \\
\hline (square root of euros) & .313 & .132 & .031 & 203 \\
\hline Food away from home (euros) & 15.27 & 5.91 & 17.49 & 7.77 \\
\hline (square root of euros) & .503 & .155 & .644 & .244 \\
\hline Transportation expenditures & -8.15 & 11.92 & 3.56 & 11.18 \\
\hline (square root of euros) & 209 & .164 & .010 & .238 \\
\hline Other expenditures (euros) & 16.12 & 9.32 & 10.64 & 15.42 \\
\hline (square root of euros) & .436 & .146 & .110 & 260 \\
\hline Total monthly expenditures (euros) & 44.36 & 24.77 & 36.11 & 35.23 \\
\hline (square root of euros) & .738 & .215 & .350 & .355 \\
\hline \multicolumn{5}{|l|}{ OCCASIONAL EXPENDITURES: } \\
\hline Home renovations: (any exterior?) & .001 & .003 & .004 & .003 \\
\hline (any other?) & .007 & .004 & .008 & .008 \\
\hline Vacation expenditures (any?) & .012 & .005 & .007 & .008 \\
\hline (euros) & 88.40 & 72.98 & -0.02 & 58.29 \\
\hline (square root of euros) & .772 & .446 & .387 & .506 \\
\hline Durables expenditures (any?) & .013 & .006 & .029 & .012 \\
\hline (euros) & 197.00 & 79.10 & 294.09 & 126.38 \\
\hline (square root of euros) & 1.437 & .513 & 2.875 & 1.055 \\
\hline \multicolumn{5}{|l|}{ OTHER OUTCOMES: } \\
\hline Happiness (level) & .125 & .025 & .007 & .054 \\
\hline Participate in PCL at Survey Date? & .008 & .005 & .016 & .009 \\
\hline Donate Survey Fee to Charity? & .014 & .008 & -.011 & .013 \\
\hline
\end{tabular}

\section{Notes to Table 7:}

Income and lottery winnings are measured in euros/10000. Household nonlottery income is measured six months before the lottery date. Total winnings include value of BMW and equal zero for nonwinners. See previous tables for definitions of other variables. All regressions include a fixed effect for lottery participation, a quadratic in the number of tickets purchased, and a dummy for residence in a winning code. Also included in all regressions are controls for the presence of a partner, number of children and its square, age and its square, education controls, and a full set of codegroup fixed effects. Bold indicates significant at 5\%; italic at 10\%. Standard errors not clustered.

1. All estimates of car ownership exclude BMW winners from the estimation sample. 
Table 8: Effects of Neighbors' Winnings on Consumption

\begin{tabular}{|c|c|c|c|c|c|c|c|c|}
\hline \multirow{4}{*}{ Outcome } & \multicolumn{8}{|c|}{ Indicator of Neighbors' Winnings } \\
\hline & \multicolumn{2}{|c|}{$\begin{array}{l}\text { Live in a winning } \\
\text { postcode? }\end{array}$} & \multicolumn{2}{|c|}{$\begin{array}{l}\text { Number of win- } \\
\text { ning households } \\
\text { in postcode }\end{array}$} & \multicolumn{2}{|c|}{$\begin{array}{c}\text { Total winnings } \\
\text { within } 25 \text { meters }\end{array}$} & \multicolumn{2}{|c|}{ Neighbor Won? } \\
\hline & $\begin{array}{l}\text { Coef- } \\
\text { ficient }\end{array}$ & $\begin{array}{l}\text { Std. } \\
\text { error }\end{array}$ & $\begin{array}{l}\text { Coef- } \\
\text { ficient }\end{array}$ & $\begin{array}{l}\text { Std. } \\
\text { error }\end{array}$ & $\begin{array}{l}\text { Coeff- } \\
\text { icient }\end{array}$ & $\begin{array}{l}\text { std. } \\
\text { error }\end{array}$ & $\begin{array}{c}\text { Coef- } \\
\text { ficient }\end{array}$ & $\begin{array}{c}\text { Std. } \\
\text { error }\end{array}$ \\
\hline & (1) & (2) & (3) & (4) & (5) & (6) & (7) & (8) \\
\hline \multicolumn{9}{|l|}{ CAR OWNERSHIP: $^{1}$} \\
\hline Acquired new car since lottery date? & .0265 & .0162 & .0030 & .0014 & .0012 & .0015 & .0485 & .0225 \\
\hline Number of cars at survey date (up to two) & .0041 & .0257 & .0036 & .0023 & .0001 & .0024 & .0077 & .0300 \\
\hline Age of main car (years) & -.4338 & .2398 & -.0475 & .0183 & -.0271 & .0211 & -.4858 & .2624 \\
\hline Car efficiency units & .0234 & .0162 & .0042 & .0015 & .0005 & .0013 & .0420 & .0226 \\
\hline \multicolumn{9}{|l|}{ MONTHLY EXPENDITURES: } \\
\hline Food at home: (euros) & -19.62 & 36.85 & -0.38 & 2.59 & -0.77 & 1.85 & -25.33 & 36.32 \\
\hline (square root of euros) & -.0818 & .4130 & .0017 & .0309 & .0135 & .0242 & .1611 & .4587 \\
\hline (change, euros) & 14.16 & 5.32 & 0.83 & 0.52 & 0.07 & 0.54 & 6.40 & 8.51 \\
\hline (change in square root) $^{2}$ & .697 & .330 & .0516 & .0320 & .0056 & .0274 & .2042 & .5042 \\
\hline Food away from home: (euros) & -10.55 & 12.81 & -0.94 & 1.01 & 0.50 & 0.74 & -7.93 & 10.65 \\
\hline (square root of euros) & -.167 & .324 & -.0033 & .0295 & .0232 & .0236 & .0230 & .3496 \\
\hline (change, euros) & 6.32 & 4.86 & 0.62 & 0.39 & 0.56 & 0.43 & 1.29 & 4.75 \\
\hline (change in square root) $^{2}$ & .3397 & .2911 & .0428 & .0258 & .0195 & .0268 & .1999 & .3301 \\
\hline Transport expenditures: (euros) & 31.37 & 21.67 & 1.43 & 1.67 & 1.84 & 2.05 & 52.57 & 34.16 \\
\hline (square root of euros) & .5260 & .3793 & .0199 & .0334 & .0387 & .0428 & 1.0201 & .4950 \\
\hline (change, euros) & 2.59 & 5.92 & -.0 .48 & 0.53 & 0.03 & 0.48 & 5.43 & 7.36 \\
\hline (change in square root) $^{2}$ & .2104 & .2844 & -.0161 & .0272 & .0176 & .0282 & .3162 & .3587 \\
\hline Other monthly: (euros) & 12.62 & 24.76 & 0.38 & 3.42 & -0.61 & 2.52 & 12.08 & 37.62 \\
\hline (square root of euros) & .3304 & .3908 & -.0142 & .0449 & .0026 & .0351 & .2795 & .5447 \\
\hline (change, euros) & 11.83 & 6.29 & 0.82 & 0.44 & -0.13 & 0.50 & 12.23 & 7.89 \\
\hline (change in square root) $^{2}$ & .7799 & .3343 & .0634 & .0246 & .0113 & .0294 & .7493 & .4244 \\
\hline Total monthly (euros): & 22.33 & 70.65 & 0.78 & 6.36 & 0.90 & 4.53 & 50.62 & 92.65 \\
\hline (square root of euros) & .3785 & .5785 & .0127 & .0591 & .0344 & .0406 & .8832 & .7562 \\
\hline (change, euros) & 31.46 & 14.57 & 2.02 & 1.30 & 1.343 & 1.665 & 18.14 & 15.93 \\
\hline (change in square root) $^{2}$ & 1.2329 & .5991 & .0954 & .0588 & .0580 & .0598 & 1.0204 & .7256 \\
\hline \multicolumn{9}{|l|}{ OCCASIONAL EXPENDITURES: } \\
\hline Home renovations: (any exterior?) & .0082 & .0072 & .0014 & .0006 & -.0006 & .0005 & -.0072 & .0107 \\
\hline (any other?) & -.0196 & .0114 & -.0010 & .0010 & .0004 & .0011 & .0048 & .0164 \\
\hline Vacation expenditures: (any?) & .0080 & .0126 & .0015 & .0010 & .0014 & .0012 & .0061 & .0172 \\
\hline (euros) & -60.84 & 95.56 & 7.15 & 4.99 & 5.85 & 4.90 & -40.11 & 96.84 \\
\hline (square root of euros) & .1260 & .7228 & .0910 & .0574 & .0865 & .0646 & .2093 & .9470 \\
\hline Durable expenditures: (any?) & -.0185 & .0175 & -.0032 & .0015 & -.0006 & .0017 & -.0230 & .0250 \\
\hline (euros) & -18.43 & 168.45 & -5.06 & 17.87 & 18.23 & 12.28 & -116.67 & 230.83 \\
\hline (square root) & -.5362 & 1.2163 & -.1298 & .1225 & .0829 & .1160 & -.7366 & 1.6566 \\
\hline \multicolumn{9}{|l|}{ OTHER OUTCOMES: } \\
\hline Happiness (level) & -.0515 & .0781 & -.0010 & .0086 & -.0086 & .0074 & .1252 & .1046 \\
\hline (change) & -.0196 & .0700 & -.0018 & .0097 & .0035 & .0057 & -.0073 & .0340 \\
\hline Participate in PCL at Survey Date? & -.0446 & .0136 & -.0031 & .0012 & -.0025 & .0010 & -.0030 & .0191 \\
\hline Donate Survey Fee to Charity? & .0739 & .0228 & .0086 & .0019 & -0037 & .0025 & .0805 & .0295 \\
\hline
\end{tabular}

Notes: Total winnings are measured in euros/10000, and equal zero for nonwinners. Monetary value of BMW is

included in winnings. See previous tables for other variable definitions. All specifications include own winnings, a fixed effect for lottery participation, a quadratic in the number of tickets purchased, the same covariates as in cols. 5 and 6 of Table 6, and a full set of codegroup fixed effects. Bold indicates significant at 5\%; italic indicates significant at $10 \%$. Standard errors clustered by postcode.

1. All estimates of car ownership exclude BMW winners from the estimation sample.

2. If the change in consumption $(x)$ is negative, this equals minus the square root of minus $x$. 
Table 9: Effects of Alternative Indicators of Winner Density on Four Measures of Car Consumption

\begin{tabular}{|c|c|c|c|c|}
\hline \multirow[b]{2}{*}{ Winner Density Indicator } & \multicolumn{4}{|c|}{ Dependent Variable } \\
\hline & New Car? & $\begin{array}{l}\text { Number of } \\
\text { Cars }\end{array}$ & $\begin{array}{c}\text { Age of main } \\
\text { car (years) }\end{array}$ & $\begin{array}{c}\text { Car efficiency } \\
\text { units }\end{array}$ \\
\hline \multicolumn{5}{|l|}{$\begin{array}{l}\text { INDICATORS BASED ON } \\
\text { HOUSE NUMBERS: }\end{array}$} \\
\hline $\begin{array}{l}\text { Had an immediate neighbor who } \\
\text { won? }\end{array}$ & $\begin{array}{l}.0458 \\
(.0225) \\
\end{array}$ & $\begin{array}{l}.0077 \\
(.0300)\end{array}$ & $\begin{array}{l}-.4858 \\
.2624 \\
\end{array}$ & $\begin{array}{l}.0420 \\
(.0226)\end{array}$ \\
\hline $\begin{array}{l}\text { Number of immediate neighbors } \\
\text { who won }(0,1 \text { or } 2)\end{array}$ & $\begin{array}{l}.0220 \\
(.0163)\end{array}$ & $\begin{array}{l}.0053 \\
(.0224)\end{array}$ & $\begin{array}{l}-.3346 \\
(.1969)\end{array}$ & $\begin{array}{c}.0284 \\
(.0177)\end{array}$ \\
\hline $\begin{array}{l}\text { Total winnings of immediate } \\
\text { neighbors (incl. value of BMW) }\end{array}$ & $\begin{array}{l}.0080 \\
(.0061)\end{array}$ & $\begin{array}{l}-.0017 \\
(.0076)\end{array}$ & $\begin{array}{l}-.1249 \\
(.0577)\end{array}$ & $\begin{array}{c}.0062 \\
(.0066)\end{array}$ \\
\hline $\begin{array}{l}\text { Number of neighbors within two } \\
\text { doors who won ( } 0 \text { to } 4)\end{array}$ & $\begin{array}{c}.0150 \\
(.0101)\end{array}$ & $\begin{array}{l}.0160 \\
(.0159)\end{array}$ & $\begin{array}{l}-.2667 \\
(.1222)\end{array}$ & $\begin{array}{c}.0260 \\
(.0123)\end{array}$ \\
\hline $\begin{array}{l}\text { Total Winnings of neighbors } \\
\text { within two doors }\end{array}$ & $\begin{array}{l}.0074 \\
(.0048)\end{array}$ & $\begin{array}{l}.0075 \\
(.0055)\end{array}$ & $\begin{array}{l}-.1034 \\
(.0409)\end{array}$ & $\begin{array}{c}.0089 \\
(.0047)\end{array}$ \\
\hline $\begin{array}{l}\text { Weighted count of neighbors } \\
\text { within } 2 \text { doors who won }{ }^{1}\end{array}$ & $\begin{array}{l}.0194 \\
(.0127)\end{array}$ & $\begin{array}{l}.0149 \\
(.0191)\end{array}$ & $\begin{array}{l}-.3262 \\
(.1546)\end{array}$ & $\begin{array}{l}.0305 \\
(.0150)\end{array}$ \\
\hline $\begin{array}{l}\text { Weighted winnings of neighbors } \\
\text { within } 2 \text { doors }{ }^{1}\end{array}$ & $\begin{array}{l}.0088 \\
(.0053)\end{array}$ & $\begin{array}{l}.0054 \\
(.0065)\end{array}$ & $\begin{array}{l}-.1277 \\
(.0504)\end{array}$ & $\begin{array}{l}.0095 \\
(.0056)\end{array}$ \\
\hline \multicolumn{5}{|l|}{$\begin{array}{l}\text { INDICATORS BASED ON } \\
\text { EUCLIDEAN DISTANCE: }\end{array}$} \\
\hline \multicolumn{5}{|l|}{ Number of winning households: } \\
\hline In same building & $\begin{array}{l}.0057 \\
(.0045)\end{array}$ & $\begin{array}{l}.0035 \\
(.0076)\end{array}$ & $\begin{array}{l}-.0527 \\
(.0705)\end{array}$ & $\begin{array}{l}.0012 \\
(.0038)\end{array}$ \\
\hline Within 25 meters & $\begin{array}{c}.0044 \\
(.0042)\end{array}$ & $\begin{array}{c}.0017 \\
(.0072)\end{array}$ & $\begin{array}{l}-.0588 \\
(.0610)\end{array}$ & $\begin{array}{c}.0013 \\
(.0034)\end{array}$ \\
\hline Within 100 meters & $\begin{array}{c}.0014 \\
(.0030)\end{array}$ & $\begin{array}{c}.0028 \\
(.0048)\end{array}$ & $\begin{array}{l}-.0481 \\
(.0448)\end{array}$ & $\begin{array}{c}.0050 \\
(.0031)\end{array}$ \\
\hline \multicolumn{5}{|l|}{ Total Amount Won: } \\
\hline In same building & $\begin{array}{l}.0008 \\
(.0015) \\
\end{array}$ & $\begin{array}{l}.0007 \\
(.0027)\end{array}$ & $\begin{array}{l}-.0248 \\
(.0234)\end{array}$ & $\begin{array}{l}.0000 \\
(.0014)\end{array}$ \\
\hline Within 25 meters & $\begin{array}{c}.0012 \\
(.0015)\end{array}$ & $\begin{array}{l}.0001 \\
(.0024)\end{array}$ & $\begin{array}{l}-.0271 \\
(.0211)\end{array}$ & $\begin{array}{l}.0005 \\
(.0013)\end{array}$ \\
\hline Within 100 meters & $\begin{array}{c}-.0001 \\
(.0011) \\
\end{array}$ & $\begin{array}{l}.0011 \\
(.0016)\end{array}$ & $\begin{array}{l}-.0588 \\
(.0610)\end{array}$ & $\begin{array}{c}.0015 \\
(.0011)\end{array}$ \\
\hline \multicolumn{5}{|l|}{$\begin{array}{l}\text { POST-CODE LEVEL } \\
\text { INDICATORS: }\end{array}$} \\
\hline Live in a Winning Postcode? & $\begin{array}{l}.0265 \\
(.0162)\end{array}$ & $\begin{array}{l}.0041 \\
(.0257)\end{array}$ & $\begin{array}{l}-.4338 \\
(.2398)\end{array}$ & $\begin{array}{c}.0234 \\
(.0162)\end{array}$ \\
\hline Number of winning households & $\begin{array}{l}.0030 \\
(.0014)\end{array}$ & $\begin{array}{l}.0036 \\
(.0023)\end{array}$ & $\begin{array}{l}-.0475 \\
(.0183)\end{array}$ & $\begin{array}{c}.0042 \\
(.0015)\end{array}$ \\
\hline Total amount won & $\begin{array}{l}.0008 \\
(.0005)\end{array}$ & $\begin{array}{l}.0012 \\
(.0009)\end{array}$ & $\begin{array}{l}-.0148 \\
(.0069)\end{array}$ & $\begin{array}{c}.0013 \\
(.0005)\end{array}$ \\
\hline Share of households that won & $\begin{array}{l}.0589 \\
(.0476)\end{array}$ & $\begin{array}{l}.0108 \\
(.0728)\end{array}$ & $\begin{array}{l}-1.5348 \\
(.6092)\end{array}$ & $\begin{array}{l}.0996 \\
(.0444)\end{array}$ \\
\hline Amt won per household & $\begin{array}{l}.0114 \\
(.0191)\end{array}$ & $\begin{array}{l}.0015 \\
(.0285)\end{array}$ & $\begin{array}{l}-.3932 \\
(.2356)\end{array}$ & $\begin{array}{c}.0248 \\
(.0169)\end{array}$ \\
\hline
\end{tabular}

Notes: Total winnings are measured in euros/10000, and equal zero for nonwinners. All estimates exclude BMWwinning households, but monetary value of BMW (valued at €25,000) is included in neighbors' winnings. See previous tables for other variable definitions. All regressions include a control for own winnings, a fixed effect for lottery participation, a quadratic in number of tickets purchased, a vector of socioeconomic characteristics, and a full set of codegroup fixed effects. Standard errors are in parentheses and are clustered at the postcode level. Bold indicates significant at $5 \%$; italic indicates significant at $10 \%$.

1. Immediate neighbors weighted by 1 ; non-immediate neighbors by 0.5 
Table 10: Car Consumption Indicators for PCL Non-Participants, by Proximity to Winners

a) By whether the next-door neighbor won the PCL

\begin{tabular}{|c|c|c|c|}
\hline & (1) & $(2)$ & (3) \\
\hline & $\begin{array}{l}\text { Living in Non- } \\
\text { Winning Codes }\end{array}$ & $\begin{array}{l}\text { Living in Winning } \\
\text { Codes, not next to a } \\
\text { PCL Winner }\end{array}$ & $\begin{array}{l}\text { Living in Winning } \\
\text { Codes, next to a } \\
\text { PCL Winner }\end{array}$ \\
\hline $\begin{array}{l}\text { New car since lottery } \\
\text { date? }\end{array}$ & $\begin{array}{l}.110 \\
(878)\end{array}$ & $\begin{array}{c}.135 \\
(244)\end{array}$ & $\begin{array}{c}.183++\neq \\
(234)\end{array}$ \\
\hline $\begin{array}{l}\text { New car between } 6 \text { and } \\
12 \text { months ago }\end{array}$ & $\begin{array}{l}.121 \\
(647)\end{array}$ & $\begin{array}{l}.133 \\
(180)\end{array}$ & $\begin{array}{c}.122 \\
(189)\end{array}$ \\
\hline $\begin{array}{l}\text { Number of cars at } \\
\text { survey date }\end{array}$ & $\begin{array}{l}.929 \\
(877)\end{array}$ & $\begin{array}{l}.975 \\
(244)\end{array}$ & $\begin{array}{c}1.077 \dagger++\neq \\
(234)\end{array}$ \\
\hline $\begin{array}{l}\text { Age of main car } \\
\text { (years) }\end{array}$ & $\begin{array}{l}7.139 \\
(660)\end{array}$ & $\begin{array}{l}7.084 \\
(178)\end{array}$ & $\begin{array}{c}6.492 \ddagger \\
(197)\end{array}$ \\
\hline Car efficiency units & $\begin{array}{l}350 \\
(851)\end{array}$ & $\begin{array}{l}371 \\
(234)\end{array}$ & $\begin{array}{c}.447 \dagger+++\neq \\
(226)\end{array}$ \\
\hline
\end{tabular}

b) By whether a PCL winner lives within two doors:

\begin{tabular}{|c|c|c|c|}
\hline & $(1)$ & $(2)$ & $(3)$ \\
\hline & $\begin{array}{l}\text { Living in Non- } \\
\text { Winning Codes }\end{array}$ & $\begin{array}{l}\text { Living in Winning } \\
\text { Codes, not within } \\
\text { two doors of a PCL } \\
\text { Winner }\end{array}$ & $\begin{array}{c}\text { Living in Winning } \\
\text { Codes, within two } \\
\text { doors of a PCL } \\
\text { Winner }\end{array}$ \\
\hline $\begin{array}{l}\text { New car since lottery } \\
\text { date? }\end{array}$ & $\begin{array}{l}.110 \\
(878)\end{array}$ & $\begin{array}{c}.153 \\
(137)\end{array}$ & $\begin{array}{l}.161 \text { 革 } \\
\text { (341) }\end{array}$ \\
\hline $\begin{array}{l}\text { New car between } 6 \\
\text { and } 12 \text { months ago }\end{array}$ & $\begin{array}{c}.121 \\
(647)\end{array}$ & $\begin{array}{l}.116 \\
(95)\end{array}$ & $\begin{array}{c}.131 \\
(274)\end{array}$ \\
\hline $\begin{array}{l}\text { Number of cars at } \\
\text { survey date }\end{array}$ & $\begin{array}{c}.929 \\
(877)\end{array}$ & $\begin{array}{l}.920 \\
(137)\end{array}$ & $\begin{array}{c}1.067 \dagger+\$+\neq \\
(341)\end{array}$ \\
\hline $\begin{array}{l}\text { Age of main car } \\
\text { (years) }\end{array}$ & $\begin{array}{l}7.139 \\
(660)\end{array}$ & $\begin{array}{c}6.978 \\
(93)\end{array}$ & $\begin{array}{l}6.706 \\
(282)\end{array}$ \\
\hline Car efficiency units & $\begin{array}{l}.350 \\
(851)\end{array}$ & $\begin{array}{l}.353 \\
(131)\end{array}$ & $\begin{array}{c}.430 \dagger+\neq+ \\
(329)\end{array}$ \\
\hline
\end{tabular}

*, **, ***: statistically different from column 1 at 10,5 and 1 percent respectively

†, ††, ††: statistically different from column 2 at at 10, 5 and 1 percent respectively

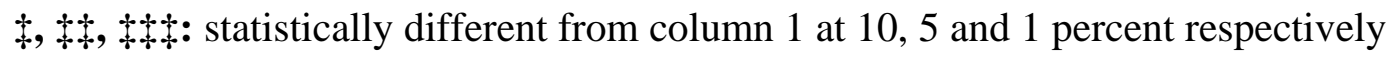

Sample sizes in parentheses. 
Table 11: Car Consumption Indicators for PCL Non-Participants who are Neighbors of Participants

a) Next-door neighbors of PCL Participants only:

\begin{tabular}{|l|c|c|}
\hline & $(1)$ & $(2)$ \\
\hline & $\begin{array}{c}\text { Living in } \\
\text { Nonwinning Codes }\end{array}$ & $\begin{array}{c}\text { Living in Winning } \\
\text { Codes }\end{array}$ \\
\hline New car since & .102 & .145 \\
lottery date? & $(88)$ & $(55)$ \\
\hline New car between 6 & .121 & .087 \\
and 12 months ago? & $(66)$ & $(46)$ \\
\hline Number of cars at & .955 & 1.073 \\
survey date & $(88)$ & $(55)$ \\
\hline Age of main car & 7.386 & 6.298 \\
(years) & $(70)$ & $(47)$ \\
\hline Car efficiency units & .352 & $.451^{*}$ \\
& $(83)$ & $(55)$ \\
\hline
\end{tabular}

b) Live within 2 doors (either way) of a PCL Participant:

\begin{tabular}{|l|c|c|}
\hline & $(1)$ & $(2)$ \\
\hline & $\begin{array}{c}\text { Living in } \\
\text { Nonwinning Codes }\end{array}$ & $\begin{array}{c}\text { Living in Winning } \\
\text { Codes }\end{array}$ \\
\hline New car since & .108 & .117 \\
lottery date? & $(157)$ & $(103)$ \\
\hline New car between 6 & .131 & .126 \\
and 12 months ago? & $(122)$ & $(87)$ \\
\hline Number of cars at & .994 & $1.155^{* *}$ \\
survey date & $(157)$ & $(103)$ \\
\hline Age of main car & 7.133 & 6.449 \\
(years) & $(128)$ & $(89)$ \\
\hline Car efficiency units & .376 & $.492^{* *}$ \\
& $(152)$ & $(101)$ \\
\hline
\end{tabular}

* Differs from column 1 at $10 \%$

** Differs from column 1 at $5 \%$

*** Differs from column 1 at $1 \%$ 
Table 12: Effects of Alternative Measures of Winner Density on Incidence of Home Renovations, by Type

\begin{tabular}{|c|c|c|}
\hline & \multicolumn{2}{|c|}{ Dependent Variable } \\
\hline Winner Density Indicator & $\begin{array}{c}\text { Exterior } \\
\text { Renovations }\end{array}$ & $\begin{array}{c}\text { Other } \\
\text { Renovations }\end{array}$ \\
\hline Live in a Winning Postcode? & .0082 & -.0193 \\
& $(.0072)$ & $\mathbf{( . 0 1 1 4 )}$ \\
\hline Number of winning households & $\mathbf{. 0 0 1 4}$ & -.0010 \\
& $\mathbf{( . 0 0 0 6 )}$ & $(.0010)$ \\
\hline Total amount won & $\mathbf{. 0 0 0 4}$ & -.0005 \\
& $\mathbf{( . 0 0 0 2 )}$ & $(.0004)$ \\
\hline Share of households that won & .0228 & -.0465 \\
& $(.0183)$ & $(.0310)$ \\
\hline Amt won per household & .0034 & -.0233 \\
& $(.0063)$ & $\mathbf{( . 0 1 2 2 )}$ \\
\hline
\end{tabular}


Table 13: Effects of Postcode and Dwelling Characteristics on Social Effects for New Car Purchases

\begin{tabular}{|c|c|c|c|}
\hline & $(1)$ & $(2)$ & $(3)$ \\
\hline Postcode Characteristic: & $\begin{array}{l}\text { Live in a } \\
\text { Winning } \\
\text { Postcode? }\end{array}$ & $\begin{array}{l}\text { Live in a Winning } \\
\text { Postcode and } \\
\text { Postcode } \\
\text { Characteristic is } \\
\text { above average: }\end{array}$ & $\begin{array}{l}\mathrm{P} \text { value for joint } \mathrm{F} \\
\text { test of (1) and (2) }\end{array}$ \\
\hline $\begin{array}{l}\text { Share of Households with } \\
\text { Two Heads }\end{array}$ & $\begin{array}{c}.0620 \\
(.0213)\end{array}$ & $\begin{array}{c}-.0661 \\
(.0308)\end{array}$ & .0138 \\
\hline $\begin{array}{l}\text { Mean Age of Household } \\
\text { Head(s) }\end{array}$ & $\begin{array}{c}.0333 \\
(.0244)\end{array}$ & $\begin{array}{l}-.0161 \\
(.0304)\end{array}$ & .3115 \\
\hline Mean Education $^{1}$ & $\begin{array}{c}.0344 \\
(.0220)\end{array}$ & $\begin{array}{l}-.0110 \\
(.0324)\end{array}$ & .2217 \\
\hline $\begin{array}{l}\text { Mean Number of } \\
\text { Children }\end{array}$ & $\begin{array}{c}.0519 \\
(.0192)\end{array}$ & $\begin{array}{l}-.0649 \\
(.0333)\end{array}$ & .0210 \\
\hline Mean Household Income & $\begin{array}{c}.0281 \\
(.0223)\end{array}$ & $\begin{array}{l}-.0062 \\
(.0316)\end{array}$ & .3354 \\
\hline Neighborhood is Urban? $^{2}$ & $\begin{array}{c}.0040 \\
(.0209) \\
\end{array}$ & $\begin{array}{c}.0700 \\
(.0334) \\
\end{array}$ & .0314 \\
\hline $\begin{array}{l}\text { Dwelling is in a multi- } \\
\text { unit building }\end{array}$ & $\begin{array}{l}-.0379 \\
(.0434)\end{array}$ & $\begin{array}{l}.0798 \\
(.0452)\end{array}$ & .0355 \\
\hline $\begin{array}{l}\text { Dwelling is in a small } \\
\text { multi-unit building }\end{array}$ & $\begin{array}{c}.0435 \\
(.0203)\end{array}$ & $\begin{array}{l}-.0564 \\
(.0335)\end{array}$ & .0783 \\
\hline $\begin{array}{l}\text { Dwelling in a large multi- } \\
\text { unit building }\end{array}$ & $\begin{array}{l}-.0208 \\
(.0258)\end{array}$ & $\begin{array}{l}.0924 \\
(.0311)\end{array}$ & .0015 \\
\hline
\end{tabular}

1. A household's education level is an integer from 1 to 8.

2. Urban means the postcode is located in one of the 30 largest cities in the Netherlands.

3. Up to four units.

4. Five or more units.

Notes: Each row corresponds to a different regression. Dependent variable in all regressions is an indicator for whether the household acquired a new car in the six months since the PCL date. All regressions include the postcode characteristic under consideration, a control for own winnings, a fixed effect for lottery participation, and a quadratic in number of tickets purchased. Standard errors are in parentheses and are clustered at the postcode level. Bold indicates significant at 5\%; italic indicates significant at $10 \%$. 
Table 14: Effects of Postcode and Dwelling Characteristics on Social Effects for Exterior Home Renovations

\begin{tabular}{|c|c|c|c|}
\hline & $(1)$ & $(2)$ & $(3)$ \\
\hline $\begin{array}{l}\text { Postcode or Dwelling } \\
\text { Characteristic: }\end{array}$ & $\begin{array}{l}\text { Number of Winning } \\
\text { Households in } \\
\text { Postcode }\end{array}$ & $\begin{array}{l}\text { Number of Winning } \\
\text { Households in } \\
\text { Postcode x Postcode } \\
\text { Characteristic is } \\
\text { above average: }\end{array}$ & $\begin{array}{l}P \text { value for joint } F \\
\text { test of (1) and (2) }\end{array}$ \\
\hline $\begin{array}{l}\text { Share of Households } \\
\text { with Two Heads }\end{array}$ & $\begin{array}{l}.0015 \\
(.0016)\end{array}$ & $\begin{array}{l}-.0004 \\
(.0016)\end{array}$ & .127 \\
\hline $\begin{array}{l}\text { Mean Age of } \\
\text { Household Head(s) }\end{array}$ & $\begin{array}{l}.0015 \\
(.0008)\end{array}$ & $\begin{array}{l}-.0009 \\
(.0012)\end{array}$ & .115 \\
\hline Mean Education $^{1}$ & $\begin{array}{c}.0011 \\
(.0009)\end{array}$ & $\begin{array}{c}.0004 \\
(.0012) \\
\end{array}$ & .072 \\
\hline $\begin{array}{l}\text { Mean Number of } \\
\text { Children }\end{array}$ & $\begin{array}{l}.0017 \\
(.0014)\end{array}$ & $\begin{array}{l}-.0007 \\
(.0015)\end{array}$ & .149 \\
\hline $\begin{array}{l}\text { Mean Household } \\
\text { Income }\end{array}$ & $\begin{array}{c}.0024 \\
(.0010)\end{array}$ & $\begin{array}{l}-.0017 \\
(.0012)\end{array}$ & .045 \\
\hline $\begin{array}{l}\text { Neighborhood is } \\
\text { Urban? }^{2}\end{array}$ & $\begin{array}{c}.0018 \\
(.0007)\end{array}$ & $\begin{array}{c}-.0024 \\
(.0009)\end{array}$ & .022 \\
\hline $\begin{array}{l}\text { Dwelling is in a } \\
\text { multi-unit building }\end{array}$ & $\begin{array}{c}-.0002 \\
(.0011)\end{array}$ & $\begin{array}{c}.0021 \\
(.0013)\end{array}$ & .020 \\
\hline $\begin{array}{l}\text { Dwelling is in a small } \\
\text { multi-unit building }\end{array}$ & $\begin{array}{c}.0005 \\
(.0007)\end{array}$ & $\begin{array}{c}.0026 \\
(.0012)\end{array}$ & .0004 \\
\hline $\begin{array}{l}\text { Dwelling in a large } \\
\text { multi-unit building }\end{array}$ & $\begin{array}{c}.0016 \\
(.0007)\end{array}$ & $\begin{array}{l}-.0006 \\
(.0011)\end{array}$ & .055 \\
\hline
\end{tabular}

1. A household's education level is an integer from 1 to 8 .

2. Urban means the postcode is located in one of the 30 largest cities in the Netherlands.

3. Up to four units.

4. Five or more units.

Notes: Each row corresponds to a different regression. Dependent variable in all regressions is an indicator for whether the household started an exterior renovation project in the six months since the PCL date. All regressions include the postcode characteristic under consideration, a control for own winnings, a fixed effect for lottery participation, and a quadratic in number of tickets purchased. Standard errors are in parentheses and are clustered at the postcode level. Bold indicates significant at 5\%; italic indicates significant at 10\%. 


\section{Appendix 1: Exogeneity Checks}

\section{Table A1: Exogeneity Checks for Own Winnings}

\begin{tabular}{|c|c|c|c|c|}
\hline \multirow{2}{*}{$\begin{array}{l}\text { Permanent or pre-Lottery } \\
\text { Characteristic: }\end{array}$} & \multicolumn{2}{|c|}{$\begin{array}{l}\text { Without codegroup } \\
\text { fixed effects }\end{array}$} & \multicolumn{2}{|c|}{$\begin{array}{c}\text { With codegroup fixed } \\
\text { effects }\end{array}$} \\
\hline & coefficent & std. error & coefficient & std. error \\
\hline Number of persons in household & .0303 & .0437 & -.0043 & .0398 \\
\hline Two-headed Household? & .0113 & .0110 & .0018 & .0105 \\
\hline Secondary Education? & -.0012 & .0085 & -.0039 & .0073 \\
\hline Higher Vocational Training or University? & -.0085 & .0116 & -.0099 & .0130 \\
\hline Age & .5132 & .3175 & .5485 & .3228 \\
\hline Number of children in household & -.0062 & .0301 & -.0214 & .0301 \\
\hline \multicolumn{5}{|c|}{ Monthly Expenditures: (euro, one year before survey date) } \\
\hline Food at home & 6.84 & 9.18 & 7.32 & 13.83 \\
\hline Food away from home & 13.31 & 5.63 & 7.69 & 5.47 \\
\hline Transportation & 12.71 & 9.91 & 15.53 & 10.18 \\
\hline Other monthly & 19.39 & 15.05 & 20.67 & 16.42 \\
\hline Total monthly & 52.91 & 34.82 & 49.88 & 35.67 \\
\hline \multicolumn{5}{|l|}{ Occasional Expenditures: } \\
\hline Exterior Home renovations before lottery (any?) & .0021 & .0087 & .0011 & .0089 \\
\hline Other Home renovations before lottery (any?) & -.0016 & .0096 & -.0083 & .0108 \\
\hline Vacation expenditures before lottery (euro) & 28.02 & 36.56 & 19.90 & 37.33 \\
\hline Durables expenditures before lottery (euro) & -171.96 & 163.18 & -193.45 & 190.95 \\
\hline Total Annual Household Income (euro, post & 920.77 & 534.27 & 591.97 & 496.65 \\
\hline \multicolumn{5}{|l|}{ tax, pre lottery) } \\
\hline Happiness & .0109 & .0458 & .0026 & .0409 \\
\hline
\end{tabular}

Notes: Coefficients from regressions of the characteristic on total amount won, with controls for whether any tickets were purchased and a quadratic in the number of tickets purchased. Winnings are in euros/10000. Total winnings are zero for nonwinners. Monetary value of BMW (valued at $€ 25,000$ ) is included in winnings. See Table 1 for additional notes and variable definitions. 
Table A2: Exogeneity Checks for Selected Indicators of Neighbors' Winnings

\begin{tabular}{|c|c|c|c|c|c|c|c|c|}
\hline \multirow{3}{*}{$\begin{array}{l}\text { Permanent or pre-Lottery } \\
\text { Characteristic: } \\
\begin{array}{l}\text { A. Without Codegroup fixed } \\
\text { effects }\end{array}\end{array}$} & \multicolumn{8}{|c|}{ Indicator of Neighbors' Winnings } \\
\hline & \multicolumn{2}{|c|}{$\begin{array}{l}\text { Live in a winning } \\
\text { postcode? }\end{array}$} & \multicolumn{2}{|c|}{$\begin{array}{l}\text { Number of win- } \\
\text { ning households } \\
\text { in postcode }\end{array}$} & \multicolumn{2}{|c|}{$\begin{array}{c}\text { Total winnings } \\
\text { within } 25 \text { meters }\end{array}$} & \multicolumn{2}{|c|}{ Neighbor Won? } \\
\hline & $\begin{array}{l}\text { Coef- } \\
\text { ficient }\end{array}$ & $\begin{array}{l}\text { Std. } \\
\text { Error }\end{array}$ & $\begin{array}{l}\text { Coef- } \\
\text { ficient }\end{array}$ & $\begin{array}{l}\text { Std. } \\
\text { error }\end{array}$ & $\begin{array}{l}\text { Coeff- } \\
\text { icient }\end{array}$ & $\begin{array}{l}\text { Std. } \\
\text { error }\end{array}$ & $\begin{array}{l}\text { Coef- } \\
\text { ficient }\end{array}$ & $\begin{array}{c}\text { Std. } \\
\text { Error }\end{array}$ \\
\hline Number of persons in household & .0433 & .1254 & .0194 & .0102 & -.0159 & .0085 & .2639 & .1132 \\
\hline Two-headed Household? & .0434 & .0338 & .0082 & .0022 & -.0034 & .0021 & .1140 & .0313 \\
\hline Secondary Education? & .0098 & .0145 & .0018 & .0009 & .0006 & .0009 & .0050 & .0170 \\
\hline Higher Vocational Training or University? & -.0258 & .0294 & -.0002 & .0031 & -.0021 & .0021 & -.0525 & .0300 \\
\hline Age & .5822 & 1.0065 & .0005 & .0628 & .0039 & .0758 & .6927 & 1.0114 \\
\hline Number of children in household & .0376 & .0604 & .0113 & .0045 & -.0082 & .0030 & .1415 & .0692 \\
\hline \multicolumn{9}{|l|}{ Monthly Expenditures, one year ago: } \\
\hline Food at home & -6.02 & 35.19 & 2.19 & 2.04 & -1.07 & 1.73 & -9.16 & 29.59 \\
\hline Food away from home & 0.15 & 11.59 & 0.40 & 0.68 & 1.43 & 1.30 & 5.36 & 10.45 \\
\hline Transportation & 12.34 & 24.35 & -0.23 & 1.01 & -0.62 & 1.56 & 39.06 & 34.55 \\
\hline Other monthly & 23.31 & 27.99 & -0.31 & 1.13 & 0.67 & 2.03 & 5.35 & 32.99 \\
\hline Total monthly & 12.58 & 70.33 & 2.48 & 3.60 & 2.17 & 5.37 & -1.38 & 61.87 \\
\hline \multicolumn{9}{|l|}{ Occasional Expenditures: } \\
\hline Exterior Home renovations before lottery? & -.0079 & .0110 & -.0008 & .0007 & -.0022 & .0005 & -.0008 & .0141 \\
\hline Other Home renovations before lottery? & -.0175 & .0193 & -.0002 & .0020 & -.0032 & .0010 & -.0105 & .0230 \\
\hline Vacation expenditures before lottery $(€)$ & 134.14 & 84.85 & 11.94 & 7.86 & 12.58 & 5.56 & 123.65 & 90.30 \\
\hline Durables expenditures before lottery $(€)$ & 28.01 & 346.72 & 21.97 & 29.42 & 1.74 & 29.82 & 94.36 & 291.28 \\
\hline Total Annual Household Income ( $€$, & 578.80 & 1217.97 & 179.18 & 110.72 & -127.28 & 74.44 & 107.90 & 1268.76 \\
\hline \multicolumn{9}{|l|}{ Post tax, pre lottery) } \\
\hline Happiness (pre-lottery) & .0835 & .1031 & .0051 & .0063 & -.0124 & .0066 & .1283 & .1098 \\
\hline \multicolumn{9}{|l|}{ B. With Codegroup fixed effects } \\
\hline Number of persons in household & -.0309 & .0713 & .0094 & .0062 & -.0021 & .0071 & .1039 & .0838 \\
\hline Two-headed Household? & -.0004 & .0218 & .0011 & .0019 & .0018 & .0018 & .0392 & .0265 \\
\hline Secondary Education? & -.0010 & .0113 & .0013 & .0008 & .0012 & .0012 & -.0044 & .0163 \\
\hline Higher Vocational Training or University? & -.0383 & .0206 & -.0036 & .0021 & -.0041 & .0024 & -.0545 & .0257 \\
\hline Age & .0164 & .8229 & -.0519 & .0677 & .0232 & .0750 & .2460 & .9806 \\
\hline Number of children in household & -.0327 & .0466 & .0076 & .0046 & -.0050 & .0038 & .0252 & .0655 \\
\hline \multicolumn{9}{|l|}{ Monthly Expenditures, one year ago: } \\
\hline Food at home & -14.57 & 32.87 & 1.88 & 2.51 & 1.62 & 1.73 & -9.95 & 37.03 \\
\hline Food away from home & -6.27 & 11.83 & -1.22 & 1.10 & 0.34 & 0.73 & -7.93 & 13.39 \\
\hline Transportation & 12.91 & 19.22 & 0.19 & 1.30 & 0.97 & 1.92 & 42.89 & 31.87 \\
\hline Other monthly & 10.83 & 30.53 & -2.41 & 2.38 & -1.45 & 2.44 & 2.60 & 37.59 \\
\hline Total monthly & -5.88 & 65.29 & -1.52 & 5.66 & 1.96 & 4.61 & -10.56 & 74.26 \\
\hline \multicolumn{9}{|l|}{ Occasional Expenditures: } \\
\hline Exterior Home renovations before lottery? & -.0065 & .0096 & -.0004 & .0009 & -.0013 & .0008 & .0006 & .0143 \\
\hline Other Home renovations before lottery? & -.0314 & .0154 & -.0023 & .0016 & -.0015 & .0011 & -.0378 & .0217 \\
\hline Vacation expenditures before lottery $(€)$ & 59.88 & 60.20 & -0.59 & 6.45 & 8.49 & 6.51 & 80.61 & 91.60 \\
\hline Durables expenditures before lottery $(€)$ & -305.24 & 295.42 & -60.79 & 53.61 & 12.16 & 24.40 & -177.67 & 343.63 \\
\hline Total Annual Household Income $(€$, & -1393.29 & 792.27 & -143.03 & 62.11 & -163.92 & 74.09 & -1940.6 & 1039.6 \\
\hline Post tax, pre lottery) & & & & & & & & \\
\hline Happiness (pre-lottery) & .0592 & .0737 & -.0024 & .0066 & -.0143 & .0072 & .0308 & .1055 \\
\hline
\end{tabular}

Notes: Coefficients from regressions of the characteristic on the neighbors' winnings indicator, controlling for a quadratic in the number of tickets purchased. All measures of winnings are in euros/10000. See previous tables for other variable definitions. 


\section{Appendix 2: Identification of Imitative versus Other Social Effects}

To focus on essentials, consider a household that did not win in the PCL (so own winnings, $W_{i}^{O}$, are zero) and let $\theta=g=h$ in (1) also equal zero. But now allow the household's consumption to depend both on its neighbor's winnings, $W_{i}^{N}$, and its neighbor's consumption, $C_{i}^{N}$, (of perhaps the same item we are studying for the original household). Thus (1) becomes:

$$
C_{i}=\alpha+\gamma W_{i}^{N}+\varphi C_{i}^{N}+e_{i}
$$

where $\varphi$ captures "imitative"social effects and $\gamma$ all other social effects.

Let the household's neighbor's consumption be given by:

$$
C_{i}^{N}=a+b W_{i}^{N}+u_{i}
$$

Under reasonable conditions, the lottery ensures that $W_{i}^{N}$ is independent of both $e_{i}$ and $u_{i}$. While it might be tempting to use $W_{i}^{N}$ as an instrument for $C_{i}^{N}$ in (A1), this is not possible unless $\gamma=0$. In other words, imitative social effects can be identified by a neighbor's-winnings instrument only under the assumption that no other social effects are present. More generally, substituting (A2) into (A1) reveals that $(\varphi b+\gamma)$ is identified from an OLS regression of consumption on neighbors’ winnings. Since imitative social effects cannot be distinguished from other social effects without additional assumptions (or a different social experiment ${ }^{41}$ ), we interpret all estimated social effects in this paper as estimates of the combined effect, $(\varphi b+\gamma)$.

\footnotetext{
${ }^{41}$ An obvious example of such an experiment would involve the random assignment of a particular consumption item to a neighboring household. In this respect, the BMW prizes in the PCL would have been ideal, had the households in the experiment not 'undone' this treatment by cashing in their BMWs. This raises interesting questions about whether imitative social effects for large consumption items can be identified without substantially coercing study participants.
} 